\title{
UTILIZAÇÃO DO RESÍDUO DE SEMENTES PROCESSADAS DE URUCUM (Bixa orellana L.) NA ALIMENTAÇÃO DE SUÍNOS EM CRESCIMENTO
}

\author{
CARLOS EDUARDO UTIYAMA
}

Dissertação apresentada à Escola Superior de Agricultura “Luiz de Queiroz”, Universidade de São Paulo, para obtenção do título de Mestre em Agronomia, Área de concentração: Ciência Animal e Pastagens.

\section{PIRACICABA}

Estado de São Paulo - Brasil

Maio - 2001 


\title{
UTILIZAÇÃO DO RESÍDUO DE SEMENTES PROCESSADAS DE URUCUM (Bixa orellana L.) NA ALIMENTAÇÃO DE SUÍNOS EM CRESCIMENTO
}

\author{
CARLOS EDUARDO UTIYAMA
}

Zootecnista

Orientador: Prof. Dr. VALDOMIRO SHIGUERU MIYADA

Dissertação apresentada à Escola Superior de Agricultura "Luiz de Queiroz", Universidade de São Paulo, para obtenção do título de Mestre em Agronomia, Área de concentração: Ciência Animal e Pastagens.

PIRACICABA

Estado de São Paulo - Brasil

Maio - 2001 
Dados Internacionais de Catalogação na Publicação (CIP)

DIVISÃo DE BIBLIOTECA E DOCUMENTAÇÃO - Campus “Luiz de Queiroz"/USP

\author{
Utiya ma, Ca rlos Eduardo \\ Utiliza ção do resíduo de sementes processadas de urucum (Bixa \\ orella na L) na a limenta ção de suínos em crescimento / Ca rlos Edua rdo \\ Utiyama. - - Piracicaba, 2001. \\ $43 \mathrm{p}$. \\ Dissertação (mestrado) - - Escola Superior de Agricultura Luiz de \\ Queiroz, 2001. \\ Bibliografia. \\ 1. Alimenta ção a nimal2. Cresc imento a nimal 3. Desempenho a nimal \\ 4. Resíduo vegetal 5. Semente de unucum 6. Subproduto vegetal 7. Suíno \\ I. Título
}

CDD 636.4084

"Permitida a cópia total ou parcial deste documento, desde que citada a fonte - $\mathrm{O}$ autor" 
Aos meus pais,

Seiji e Solange, que dedicaram e dedicam suas vidas à minha, sendo

eternamente grato;

Ao meu irmão,

Luis Gustvao, que esteve sempre atento aos meus momentos de dificuldade, estendendo-me a mão;

Aos meus futuros sogros,

Afonso e Lúcia, que dividem a suas atenções com um quarto

filho;

À minha mãe de profissão

Jacinta, que me guiou, guia e guiará, durante a longa e difícil

jornada da vida profissional;

Com muito amor e gratidão,

Dedico. 
À minha noiva e futura esposa,

Liliana, sempre solidária, compamnheira e compreeensiva, alvo de todo meu amor e dedicação,

Ofereço. 


\section{AGRADECIMENTOS:}

Ao CNPq, pela Bolsa concedida durante o curso;

Ao Prof. Dr. Valdomiro Shigueru Miyada, pela amizade, orientação e confiança;

Ao Prof. Dr. José Fernando Machado Menten, pelos conselhos, apoio e auxílio;

Ao Prof. Dr. Irineu Umberto Packer, pelos valiosíssimos conselhos e sugestões no momento da análise dos dados;

À Profa. Dra. Catarina Abdalla Gomide, pelo apoio e incentivo de inestimáve is valores;

Ao Prof. Dr. Virgílio F. do Nascimento Filho, responsável pelo Laboratório de Instrumentação Nuclear do CENA/USP, que muito colaborou para as análises de óxido crômico;

À empresa MOINHO PRIMOR S.A., pelo fornecimento do urucum e apoio financeiro;

Aos funcionários do Setor de Suinocultura do Departamento de Produção Animal da ESALQ, Srs. Pires, Ventura, Galvão e Adão;

Aos estagiários do Setor de Suinocultura do Departamento de Produção Animal da ESALQ, Gilberto, Urbano e Adriana, pelo apoio durante o transcorrer dos experimentos;

Aos colegas de turma, zootecnistas e amigos Adriana Figueiredo, Adriana Pedroso e Flávio Longo, pelo apoio e amizade durante todo o curso, além do grande e valioso auxílio durante os experimentos;

À zootecnista Claudia Paz, doutoranda e colega de turma, que muito colaborou no momento da análise dos dados, com conselhos e sugestões; 
À amiga e zootecnista Renata Duarte, que colaborou, de forma essencial, nas análises laboratoriais de algumas amostras;

Ao zootecnista Leandro Portz, doutorando e colega de turma, que muito colaborou com sugestões, esclarecimentos e auxílio, no uso do óxido crômico como marcador;

Àqueles que de alguma maneira, direta ou indiretamente, contribuíram para a realização deste trabalho, a minha enorme gratidão. 


\section{SUMÁRIO}

Página

LISTA DE TABELAS .......................................................................... viii

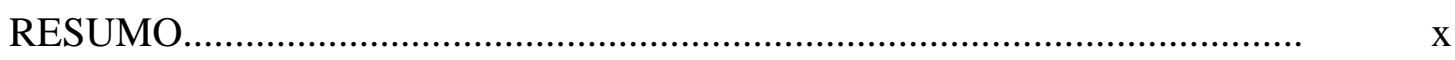

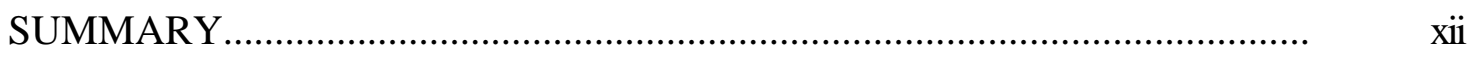

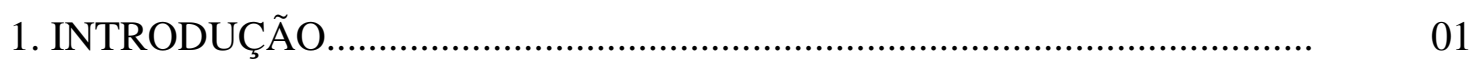

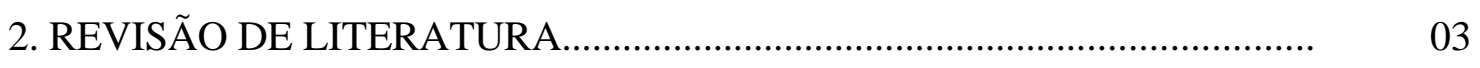

2.1. A importância e industrialização do urucum no Brasil.................................... 03

2.2. Caracterização do resíduo de sementes processadas de urucum...................... 04

2.3. Propriedades do urucum......................................................................... 05

2.4. A utilização do resíduo de semente processada de urucum na alimentação

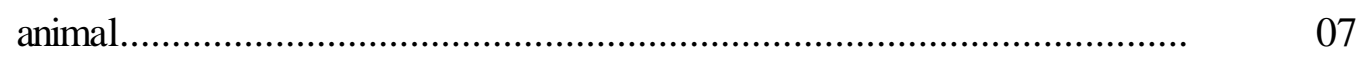

2.5. Outros subprodutos ou ingredientes alternativos utilizados na alimentação de suínos.

3. MATERIAL E MÉTODOS...................................................................

3.1. Instalações e animais......................................................................... $\quad 10$

3.2. Ensaio de digestibilidade (Experimento I).............................................. 11

3.2.1. Análises laboratoriais............................................................... 13

3.2.2. Determinação da energia e da proteína digestíveis............................. 14

3.3. Ensaio de desempenho (Experimento II)............................................... 15

3.3.1. Tratamentos..................................................................... 15

3.3.2. Delineamento experimental...................................................... 17

3.3.3. Análise dos dados................................................................ 17

4. RESULTADOS E DISCUSSÃO............................................................... 18

4.1. Ensaio de digestibilidade (Experimento I)................................................ 18

4.2. Ensaio de desempenho (Experimento II)............................................... 21 
Página

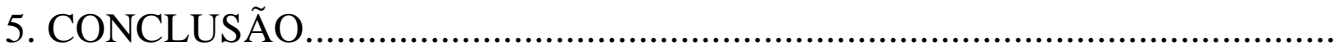

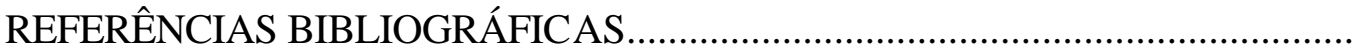




\section{LISTA DE TABELAS}

TABELA N $\mathrm{N}^{\circ}$

Página

1 Composição percentual e valores calculados da ração basal do ensaio de digestibilidade (Experimento I)

2 Composição dos principais componentes das rações experimentais (Experimento II)

3 Composição percentual das rações experimentais e valores calculados do ensaio de desempenho (Experimento II)

4 Resultados do ensaio de digestibilidade aparente da energia bruta do resíduo de semente processada de urucum (Experimento I).

5 Resultados do ensaio de digestibilidade aparente da proteína bruta do resíduo de semente processada de urucum (Experimento I)

6 Valores médios de consumo diário de ração (CDR, kg) dos leitões, durante o período experimental de 35 dias (Experimento II).

7 Valores médios de ganho diário de peso (GDP, kg) dos leitões, durante o período experimental de 35 dias (Experimento II)...............

8 Valores médios de conversão alimentar (CA) dos leitões, durante o período experimental de 35 dias (Experimento II)

9 Valores médios dos tratamentos para consumo diário de ração (CDR, $\mathrm{kg}$ ), ganho diário de peso (GDP, kg) e conversão alimentar (CA), durante o período experimental de 35 dias (Experimento II). 
TABELA N ${ }^{\circ}$

Página

A1 Cálculo de restrição alimentar durante o período de coleta do ensaio de digestibilidade (Experimento I)

A2 Composição das amostras de fezes, ração basal, ração teste e urucum (Experimento I)

A3 Composição das amostras de fezes, ração basal, ração teste e urucum, em matéria seca (Experimento I)

A4 Peso vivo dos animais (kg), obtidos semanalmente, considerando a média da unidade experimental (Experimento II)............................

A5 Resultados de consumo diário de ração (CDR, kg), considerando a média da unidade experimental (Experimento II)..............................

A6 Resultados de ganho diário de peso (GDP, em kg), considerando a média da unidade experimental (Experimento II)......

A7 Resultados de conversão alimentar (CA), considerando a média da unidade experimental (Experimento II)

A8 Registro de temperaturas $\left({ }^{\circ} \mathrm{C}\right)$ máximas e mínimas durante o período experimental (Experimento II) 


\title{
UTILIZAÇÃO DO RESÍDUO DE SEMENTES PROCESSADAS \\ DE URUCUM (Bixa orellana L.) NA ALIMENTAÇÃO DE SUÍNOS EM CRESCIMENTO
}

\author{
Autor: CARLOS EDUARDO UTIYAMA \\ Orientador: Prof. Dr. VALDOMIRO SHIGUERU MIYADA
}

\section{RESUMO}

Dois experimentos foram realizados, com o objetivo de avaliar a viabilidade da utilização do resíduo de semente processada de urucum, como um alimento alternativo para suínos na fase de crescimento.

O Experimento I constituiu-se de um ensaio de digestibilidade, sendo utilizados quatro fêmeas e quatro machos castrados, mestiços Landrace x Large White, com peso médio de 39,23 kg. Pela técnica de coleta parcial de fezes, utilizando o óxido crômico $\left(\mathrm{Cr}_{2} \mathrm{O}_{3}\right)$ como marcador, determinaram-se os valores dos coeficientes de digestibilidade aparente da energia e da proteína do resíduo de semente processada de urucum, sendo, respectivamente, de 63,2 e 59,7\%. Aplicando estes coeficientes sobre os valores de energia bruta $(3.740 \mathrm{kcal} / \mathrm{kg}$ ) e proteína bruta $(14,73 \%)$, foram determinados os valores de $2.365 \mathrm{kcal} / \mathrm{kg}$ e $8,80 \%$ para, respectivamente, a energia e a proteína digestíveis do alimento em questão.

O valor de energia digestível do resíduo de semente de urucum foi empregado na formulação das rações experimentais do ensaio de desempenho. Foram utilizados 40 suínos (20 machos castrados e 20 fêmeas) com peso médio inicial de $22,49 \mathrm{~kg}$. Os tratamentos consistiram de cinco rações com níveis de 0,0, 2,5, 5,0, 7,5 e $10,0 \%$ de inclusão do resíduo de semente processada de urucum, sendo as mesmas 
isoenergéticas $(3.400 \mathrm{kcal} / \mathrm{kg}$ de energia digestível), isoprotéicas (18\% de proteína bruta) e isolisínicas $(0,90 \%)$. Água e ração foram fornecidas à vontade durante todo o período experimental de 35 dias. O delineamento experimental foi o de blocos casualizados, com quatro repetições por tratamento e dois animais (um macho castrado e uma fêmea) por unidade experimental (baia). As pesagens dos animais e o cálculo do consumo diário de ração (CDR), ganho diário de peso (GDP) e conversão alimentar (CA) foram feitos semanalmente.

Não houve diferença $(\mathrm{P}>0,05)$ entre os níveis de inclusão de resíduo de semente de urucum na dieta sobre o CDR, GDP e CA dos animais. Mesmo após a decomposição dos graus de liberdade dos tratamentos em seus componentes linear, quadrático, cúbico e de quarto grau pelos polinômios ortogonais, não foi detectada $(\mathrm{P}>0,05)$ qualquer tendência das referidas variáveis. Assim, pode-se concluir que, em relação a uma dieta padrão de milho e farelo de soja, uma vez mantidas as dietas isoenergéticas, isoprotéicas e isolisínicas, o resíduo de semente de urucum pode ser incluído até o nível de 10\%, sem influenciar o desempenho dos suínos em crescimento (22,5 a 53,5 kg PV). 


\title{
USE OF ANNATTO (Bixa orellana L.) SEED BYPRODUCT FOR GROWING PIGS
}

\author{
Author: CARLOS EDUARDO UTIYAMA \\ Adviser: Prof. Dr. VALDOMIRO SHIGUERU MIYADA
}

\section{SUMMARY}

The purpose of this study was to evaluate the use of annatto (Bixa orellana L.) seed byproduct as an alternative feed ingredient for growing pig.

In Experiment I, eight Landrace x Large White crossbred growing pigs (four barrows and four gilts), averaging $39.23 \mathrm{~kg}$ live weight, were used for digestibility assay. The method was the partial faeces collection, using the chromium oxide $\left(\mathrm{Cr}_{2} \mathrm{O}_{3}\right)$ as fecal marker. The determined apparent digestibility coefficients of energy and protein were, respectively, 63.2 and $59.7 \%$, resulting in 2,365 $\mathrm{kcal} / \mathrm{kg}$ of digestible energy and $8.8 \%$ of digestible protein.

In Experiment II, forty pigs were assigned to five treatments, in a randomized complete block design based on initial live weight and genetic group (30 Seghers and 10 Landrace x Large White crossbred pigs). The five treatments consisted of dietary levels of $0.0,2.5,5.0,7.5$ and $10.0 \%$ of annatto seed byproduct. All experimental diets were formulated to contain the same levels of digestible energy $(3,400 \mathrm{kcal} / \mathrm{kg})$, crude protein $(18.0 \% \mathrm{CP})$ and total lysine $(0.90 \%)$. Pigs were housed in 20 pens, with two pigs (a barrow and a gilt) per pen (experimental unit), and four replications per treatment. Feed and water were given ad libitum to pigs during all 35day experimental period. The live weight and the data of feed intake per pen were 
registered every week.

Pig performance data, such as daily feed intake (DFI), average daily gain (ADG) and feed conversion (FC) were analyzed by polynomial regression and the treatment means were compared by Tukey test. No treatment effects were observed on DFI, ADG and FC. Therefore, it can be concluded that the annatto seed byproduct can be used up to $10 \%$ in growing pig diets, adjusted for the same levels of energy and protein. 


\section{INTRODUÇÃO}

A carne suína é a carne mais produzida e consumida mundialmente, representando, 39\% da produção mundial de carnes (FAO, 2001). A indústria suinícola brasileira progrediu de forma significativa nos últimos anos, tendo atualmente uma taxa anual de crescimento de 5,6\%, resultando numa produção de 1.900 .000 t, no ano de 2000 (Gessulli Agribusiness, 2001). Este aumento foi concretizado devido à evolução dos conhecimentos na área da nutrição, do melhoramento genético, sanidade, manejo, ambiência e instalações, sendo que, hoje se tem uma excelente tecnologia para produção de proteína animal pela espécie suína. Toda esta evolução na área técnica, por sua vez, foi gerada a partir de esforços e investimentos provindos de instituições de pesquisa e empresas privadas.

Apesar de toda prosperidade, a indústria de produção suína atual tem sempre operado em estreitas margens de lucro. Assim, uma das principais metas da cadeia produtiva de carne suína, a exemplo das de outras espécies, é a redução dos custos de produção. Em espécies monogástricas, como os suínos, aproximadamente 70\% dos custos de produção cabe à alimentação dos animais (Albino \& Silva, 1996).

Assim, fica evidenciada a grande importância que a alimentação exerce,

tanto no aspecto técnico/produtivo, quanto no aspecto econômico. É dentro deste contexto que, nos últimos anos, as pesquisas, envolvendo a utilização de alimentos alternativos de menor custo para os animais, vêm aumentando em número e em qualidade. Essas pesquisas têm envolvido o estudo de subprodutos ou resíduos, resultantes do processamento industrial de produtos agrícolas e de práticas modernas de mecanização agrícola (Gomes, 1996). 
Portanto, as pesquisas têm sido fundamentais para (1) fornecer subsídios que permitam o eficiente emprego dos chamados alimentos alternativos, que eventualmente poderiam estar sendo perdidos e (2) conhecer as limitações (fatores limitantes) destes materiais para as diferentes categorias dentro de cada espécie animal (Miyada, 1987).

O resíduo de sementes processadas de urucum (Bixa orellana L.) é um subproduto de baixo custo descartado pela indústria em quantidades de aproximadamente $2.600 \mathrm{t}$ ao ano (Pimentel, 1995). Atualmente, ainda é muito pequeno o número de trabalhos de pesquisa a respeito da utilização deste resíduo na alimentação animal.

Portanto, este trabalho teve como objetivo determinar a digestibilidade da energia e da proteína do resíduo de semente de urucum, assim como, os efeitos da inclusão de até $10 \%$ desse subproduto na dieta de suínos em crescimento, sobre o desempenho dos animais. 


\section{REVISÃO DE LITERATURA}

\subsection{A importância e a industrialização do urucum no Brasil}

A cultura do urucum (Bixa orellana L.) visa a produção de vários tipos de corantes extraídos de suas sementes (Rodrigues, 1995). Tais corantes são muito importantes nas indústrias farmacêuticas, têxteis, de laticínios, de alimentos, de bebidas, de tintas e de cosméticos (Carvalho, 1999 e Melo \& Lima ${ }^{1}$, citados por Rodrigues, 1995). A importância se deve, principalmente, às limitações no uso de corantes artificiais em alimentos, levando a indústria alimentícia a optar pela exploração de corantes naturais (Torres, 1986), em especial os extraídos da semente de urucum: bixina e norbixina (Tonani, 1995).

No Brasil, o comércio de sementes de urucum está estimado em aproximadamente 9.000 t/ano. Do total de sementes, 20 a 30\% são exportados na forma in natura e 28,6\% são industrializados para a produção de corantes e, aproximadamente, $57 \%$ das sementes produzidas são comercializadas na forma de sementes moídas integralmente, produto conhecido como colorau (Pimentel, 1995).

O principal pigmento extraído da semente de urucum (bixina), representa cerca de $6 \%$ do peso total da semente, implicando em volumes muito grandes de resíduos gerados a partir do processamento industrial da semente (Tonani, 1995). Existem dois métodos principais de extração da bixina do urucum, os quais são

\footnotetext{
${ }^{1}$ Melo \& Lima. A situação do urucum no Brasil e perspectivas. In: SÃO JOSÉ, A.R. \&
} REBOUÇAS, T.N.H. A cultura do urucum no Brasil. Vitória da Conquista, UESB. 1990. p.9-19. 
largamente utilizados em escala industrial: (1) extração por centrifugação em água e (2) extração por centrifugação em óleo. Em ambos os processos, a bixina é o principal pigmento extraído (Paschoini, 2000), deixando resíduos de sementes que são totalmente descartados pelas indústrias.

As indústrias de urucum, em sua maioria (mais de 90\%), localizam-se no Estado de São Paulo e o progresso apresentado pelas mesmas no setor de pesquisa e desenvolvimento, nos últimos anos, permite ampliar, a cada momento, o espectro de utilização do urucum e seus resíduos (Oliveira, 1991).

\subsection{Caracterização do resíduo de sementes processadas de urucum}

Após a extração industrial dos pigmentos naturais (bixina e norbixina) do urucum, gera-se um subproduto, o resíduo de sementes processadas de urucum o qual tem sido descartado na maioria dos casos, sem nenhuma função na alimentação, adubação orgânica ou reciclagem de nutrientes.

Com o objetivo de utilizar esse resíduo em alguma atividade produtiva, Paschoini (2000) submeteu, inicialmente, os resíduos de sementes provenientes da extração por centrifugação em água a um processo de secagem. Após seco, o material resultante foi misturado ao resíduo proveniente da extração de bixina por centrifugação em óleo e, posteriormente, moído. Como resultado, formou-se um farelo com características favoráveis para ser utilizado na alimentação animal.

Ao determinar a composição bromatológica deste subproduto, Wurts \& Torreblanca (1983) encontraram valores, com base na matéria seca, de 13,7\% de proteína bruta, $14,4 \%$ de fibra bruta, $1,1 \%$ de extrato etéreo, 5,9\% de matéria mineral e $64,9 \%$ de extrativo não nitrogenado. Apesar de ser um subproduto, o resíduo de semente processada de urucum tem apresentado composição bromatológica pouco variável. Tonani (1995) determinou os seguintes valores com base em matéria seca: 13,5\% de proteína bruta, $15 \%$ de fibra bruta, $1,5 \%$ de extrato etéreo, 6,2\% de matéria mineral e $63,8 \%$ de extrativo não nitrogenado. São valores muito próximos aos encontrados por Wurts \& Torreblanca (1983). Tonani (1995) ainda afirmou que, pela composição 
bromatológica, o resíduo de semente de urucum se assemelha muito ao farelo de trigo, podendo ser considerado um alimento concentrado, uma vez que o conteúdo de fibra bruta é inferior a $18 \%$.

Analisando a qualidade da proteína, Wurts \& Torreblanca (1983) determinaram as porcentagens de todos os aminoácidos na matéria seca, encontrando os seguintes valores: lisina $(0,88 \%)$, isoleucina $(0,49 \%)$, metionina $(0,19 \%)$ e triptofano $(0,10 \%)$. Quanto à fração mineral, o resíduo de semente de urucum apresenta $0,16 \%$ de cálcio e $0,35 \%$ de fósforo e é muito pobre em ferro $(0,006 \%)$, segundo Wurts \& Torreblanca (1983).

As quantidades de tiamina e riboflavina presentes na semente in natura são, respectivamente, de 0,23 e $0,52 \mathrm{mg} / 100 \mathrm{~g}$ de matéria seca. No entanto, no resíduo de semente processada de urucum estas quantidades são inferiores $(0,10$ e 0,32 mg/100g de matéria seca, respectivamente), sendo que o mesmo alimento não deve ser considerado uma fonte importante das referidas vitaminas (Wurts \& Torreblanca, 1983).

Em adição, Wurts \& Torreblanca (1983) analisaram alguns fatores antinutricionais no resíduo de semente de urucum. A presença de antitripsina, assim como de hemaglutininas, glicosídeos cianogênicos e alcalóides não foi constatada. Apenas pequenas quantidades de saponinas foram encontradas (438 $\mu \mathrm{g} / \mathrm{g}$ ), o que, possivelmente, não restringe o uso do resíduo de semente de urucum na alimentação animal.

\subsection{Propriedades do urucum}

O resíduo de semente processada de urucum possui $1,5 \%$ de extrato etéreo (Tonani, 1995). Tal fração é basicamente representada pelos pigmentos e substâncias lipídicas remanescentes do processamento industrial de produção de corantes ou extratos de urucum. Esta fração está relacionada com as propriedades químicas presentes nos extratos de urucum e que podem, de certa forma, estarem também presentes nos resíduos de sementes. 
Diversos princípios ativos estão presentes no urucunzeiro, principalmente na parte aérea (folhas e ramos). Extratos de folhas e ramos têm demonstrado eficiência no combate a microrganismos causadores de disenteria (Lentz et al., 1998) e infecções leves e, até mais graves (Cáceres et al., 1998 e Freixa et al., 1998).

Uma grande gama de microrganismos (bactérias, fungos e protozoários) são susceptíveis a certos compostos presentes nos extratos de urucum, sendo alguns deles: Pseudomonas aeruginosa, Salmonella typhi, Staphylococcus aureos, Escherichia coli, Serratia marcescens, Candida albicans, Cadida utilis, Cryptococcus neoformans, Aspergillus flavus e Aspergillus niger (Cáceres et al., 1998 e Irobi et al., 1996). Irobi et al. (1996) afirmaram, ainda, que o efeito atimicrobiano é mais acentuado contra bactérias gram positivas como os estreptococos e estafilococos, enquanto que, a ação contra Escherichia coli, Serratia marcescens, Cadida utilis e Aspergillus niger é mais leve. Em extratos obtidos apenas das sementes de urucum, a eficiência é comprovada apenas contra Staphylococcus aureos (Chadriandy et al., 1999).

Os extratos de urucum, principalmente das folhas, ainda possuem propriedades inseticidas de média potência (Broussalis et al., 1999), podendo inclusive, ser um inibidor parcial do Plasmodium falciparum, agente causador da malária (Baelmans et al., 2000). Uma outra propriedade desta planta, está relacionada à amenização ou neutralização da ação hemorrágica do veneno de Bothrops atrox, uma serpente muito comum na região noroeste da Colômbia (Otero et al., 2000a, 2000b).

Por outro lado, alguns princípios podem também trazer consequências indesejáveis. Existem suspeitas de que a casca da semente do urucum pode causar efeitos tóxicos no pâncreas e fígado, acompanhados de hiperglicemia e uma aparente tendência no aumento dos níveis de insulina (Catálogo Rural, 2001 e Morrison et al., 1991).

Dos princípios já citados, os antimicrobianos seriam os mais importantes à produção animal. No entanto, além de ainda haver dúvidas a respeito de tais princípios, deve-se salientar que são necessários estudos quali-quantitativos dos mesmos no resíduo de sementes processadas de urucum. 


\subsection{A utilização do resíduo de sementes processadas de urucum na alimentação animal}

$\mathrm{Na}$ literatura atual, são raros os trabalhos disponíveis envolvendo o subproduto na alimentação de animais não ruminantes ou ruminantes. Em bovinos, Tonani (1995) concluiu que, em níveis de $26 \%$ na dieta, o resíduo de semente processada de urucum não alterou a digestibilidade dos nutrientes e nem o desempenho e a conversão alimentar dos animais. Apenas houve a constatação de que a ingestão de matéria seca tende a ser reduzida à medida que há um aumento na porcentagem de resíduo de urucum na dieta. Além disso, a digestibilidade da fibra do subproduto é baixa, devido, possivelmente, aos altos teores de FDN e FDA. Estas frações encontram-se, principalmente, no tegumento que reveste a semente do urucum e não são retirados nos processos industriais.

Em animais não ruminantes, Squib et al. (1953), citados por Tonani (1995), constataram que houve redução no ganho de peso de frangos, quando se substituiu o milho pelo resíduo de urucum em 30 e 50\%, provavelmente devido ao aumento do teor de fibra bruta e redução dos níveis de energia da dieta. Ao utilizar níveis crescentes $(0,5,10$ e $15 \%)$ de resíduo de urucum na alimentação de suínos, Alva (1991), citado por Tonani (1995), observou que os melhores valores para conversão alimentar, ingestão de matéria seca e ganho de peso foram obtidos com a inclusão de 5\% do subproduto de urucum na dieta.

Adicionalmente, sabe-se que a utilização de extrato de urucum na alimentação de poedeiras, para intensificar a pigmentação da gema de ovos, é eficaz (Silva, 2000). Tal produto corresponde a fração que foi extraída da semente de urucum e possui uma concentração extremamente alta de bixina (Hernandez \& Rusig, 1992), o que lhe confere tal propriedade. No entanto, não há efeito sobre o desempenho dos animais. 


\subsection{Outros subprodutos ou ingredientes alternativos utilizados na alimentação de suínos}

Diante da escassez de informações a respeito do uso do resíduo de semente processada de urucum na alimentação animal, principalmente de suínos, procuraram-se informações sobre a mesma utilização de outros subprodutos, resíduos e alimentos alternativos.

Alguns destes alimentos possuem composições bromatológicas, de certa forma, semelhantes ao resíduo de semente de urucum, como é o caso do farelo de trigo (Albino \& Silva, 1996 e Fialho et al., 1986) e do farelo de arroz desengordurado (Albino \& Silva, 1996; Lima et al., 1999 e Miyada et al., 1993). Tais alimentos são utilizados como fontes de energia e proteína, já que possuem em média 14-17\% de proteína bruta e 2.300-2.650 kcal/kg de energia digestível. De forma geral, o uso desses alimentos para suínos em crescimento tem proporcionado resultados satisfatórios, criando assim perspectivas para o uso do resíduo de semente de urucum.

Frequentemente, alguns ajustes ou suplementações são necessários ao se utilizarem tais ingredientes (Miyada et al., 1993). No caso do uso de farelo de trigo, há necessidade de suplementação de aminoácidos (lisina e treonina) para que não haja perda no desempenho dos animais (Myer et al.,1996).

O teor de fibra na dieta tende a aumentar ao se utilizarem alimentos como o farelo de trigo, em substituição ao milho e ao farelo de soja, proporcionando assim, menor conteúdo de energia digestível (Ferreira et al., 1997 e Fialho et al., 1986). Portanto, um ajuste energético (Miyada et al., 1993) feito pela inclusão de óleos e gorduras, em muitas ocasiões, é necessário.

Fialho et al. (1986) relataram queda nos coeficientes de digestibilidade da dieta ou piora na conversão alimentar quando se utilizam níveis de inclusão de $30 \%$ de farelo de trigo. Algo semelhante ocorre quando se inclui 20 a $25 \%$ de farelo de arroz desengordurado na dieta de suínos em crescimento-terminação, havendo prejuízo no desempenho (Borin Jr et al., 1988 e Ferreira et al., 1984). 
A inclusão de alimentos alternativos na dieta de suínos em crescimento exige atenção aos níveis de energia e proteína (aminoácidos) dos mesmos e das dietas que os contem, a fim de se evitar quedas no desempenho dos animais. 


\section{MATERIAL E MÉTODOS}

Foram conduzidos dois experimentos, sendo que o Experimento I consistiu de um ensaio de digestibilidade, num período de 12 dias, objetivando determinar os valores de energia e proteína digestíveis do resíduo de semente processada de urucum. O Experimento II foi destinado à avaliação do desempenho de suínos durante cinco semanas na fase de crescimento (70 aos 105 dias de idade), utilizando cinco níveis dietéticos de resíduo de semente processada de urucum.

\subsection{Instalações e animais}

Os experimentos foram conduzidos numa instalação experimental do Setor de Suinocultura do Departamento de Produção Animal da ESALQ/USP Piracicaba/SP, com uma área de aproximadamente $152 \mathrm{~m}^{2}(19,2$ x 7,9 m). Esta instalação era dotada de muretas de alvenaria de 1,20 m de altura e pé-direito de 2,8 m,

possuindo 32 baias com divisórias metálicas vazadas, dispostas em duas faixas de 16 baias de cada lado. Cada baia possuía uma área total de 3,48 $\mathrm{m}^{2}(1,2 \times 2,9 \mathrm{~m})$, sendo providas de comedouros automáticos e bebedouro tipo chupeta. A área encontrada imediatamente abaixo do bebedouro era de piso vazado, enquanto que o restante era compacto.

Os animais do Experimento I foram cedidos pelo próprio Setor de Suinocultura do Departamento de Produção Animal da ESALQ/USP, tendo sido priorizada a seleção de um grupo de leitões homogêneos em relação ao peso e à idade. 
Para o Experimento II foram utilizados 40 animais, sendo 10 leitões mestiços (Landrace x Large White), cedidos pelo mesmo Setor de Suinocultura, e 30 leitões Seghers.

\subsection{Ensaio de digestibilidade (Experimento I)}

Foram utilizados oito animais de peso médio de 39,23 $\pm 2,85 \mathrm{~kg}$, divididos em dois tratamentos, o controle (ração basal) e o teste ( $20 \%$ de resíduo de semente processada de urucum).

O método da coleta parcial de fezes, de acordo com a metodologia descrita por Moreira (1993), foi empregado utilizando-se o óxido crômico $\left(\mathrm{Cr}_{2} \mathrm{O}_{3}\right)$ como marcador, adicionado às rações experimentais na concentração de $0,5 \%$.

Antes do período experimental de 12 dias, foram realizados testes de consumo de alimento para determinar o nível máximo de inclusão de resíduo de semente processada de urucum à ração basal, para que não houvesse prejuízo no consumo de alimento pelos animais no período de coleta de fezes. Assim, estabeleceu-se a inclusão de $20 \%$ de alimento teste à ração basal.

A ração basal foi formulada de acordo com Rostagno et al. (2000). A composição percentual e os valores calculados dos nutrientes da ração basal são apresentados na Tabela 1 .

Os primeiros sete dias do período experimental corresponderam ao período de adaptação. Nestes dias foi determinado o consumo voluntário diário dos animais para ambas as rações (basal e teste), em duas alimentações diárias, com água fornecida à vontade. 
Tabela 1. Composição percentual e valores calculados da ração basal do ensaio de digestibilidade (Experimento I).

\begin{tabular}{lc}
\hline Ingredientes & Ração basal \\
\hline Milho & 76,76 \\
Farelo de soja & 18,08 \\
Óleo vegetal & 0,93 \\
Calcário & 1,06 \\
Fosfato bicálcico & 1,34 \\
Sal & 0,33 \\
Pré-mistura: & 1,50 \\
$\quad$ Milho, veículo & $(1,22)$ \\
$\quad$ L-Lisina.HCl & $(0,08)$ \\
$\quad$ Suplemento vitamínico b & $(0,10)$ \\
$\quad$ Suplemento mineral & $(0,10)$ \\
& \\
Valores Calculados: & \\
$\quad$ Energia digestível, kcal/kg & 3.400 \\
$\quad$ Proteína bruta, \% & 15,00 \\
$\quad$ Lisina, \% & 0,77 \\
Cálcio, \% & 0,80 \\
Fósforo total, \% & 0,56 \\
\hline${ }^{a}$ Contendo $78 \%$ L-Lisina.
\end{tabular}

${ }^{\mathrm{b}}$ Quantidades supridas por kg de ração: vit. A, 6000 UI; vit. D 3 , 1500 UI; vit. E, 15 UI; vit. $\mathrm{K}_{3}, 1,5 \mathrm{mg}$; vit. $B_{1}, 1,35 \mathrm{mg}$; vit. $B_{2}, 4 \mathrm{mg}$; vit. $B_{6}, 2 \mathrm{mg}$; vit. $B_{12}, 20 \mathrm{mg}$; ácido nicotínico, $20 \mathrm{mg}$; ácido fólico, 0,6 mg; biotina, 0,8 mg; ácido pantotênico, 9,35 mg; selênio 0,3 mg.

${ }^{\mathrm{c}}$ Quantidades supridas por kg de ração: iodo, $1,5 \mathrm{mg}$; cobalto, $1 \mathrm{mg}$; cobre, $10 \mathrm{mg}$; zinco $100 \mathrm{mg}$; ferro, $100 \mathrm{mg}$; manganês, $40 \mathrm{mg}$.

O consumo diário no período de coleta ( 5 dias) foi restrito de acordo com os seguintes cálculos:

\section{CRR = I x Peso metabólico,}

onde:

- $\quad$ CRR = Consumo restrito de ração $(\mathrm{kg})$;

- $\quad$ I = Índice = Consumo de ração médio dos 7 dias (kg) / Peso metabólico;

- $\quad$ Peso metabólico $(\mathrm{kg})=(\text { Peso vivo })^{0,75}$. 
O índice I foi calculado para todos os animais, mas foi adotado o menor valor de I encontrado para o cálculo do CRR. Apesar de haver a padronização do valor de I, o CRR foi determinado individualmente, sendo calculado também em função do peso de cada animal, como ilustrado na Tabela A1.

A coleta de fezes foi feita duas vezes ao dia, diretamente do reto dos

animais. As amostras foram imediatamente acondicionadas em sacos plásticos e congeladas para posteriores análises laboratoriais.

\subsubsection{Análises laboratoriais}

As amostras de fezes foram descongelas, homogeneizadas e secas em estufa de $65^{\circ} \mathrm{C}$ por 72 horas. Tanto as amostras secas de fezes, quanto as amostras de ração e urucum, foram moídas em peneira de um mm para as análises químicas.

Todas as análises foram feitas em duplicatas. As determinações de energia bruta (empregando a bomba calorimétrica automática modelo PARR 1261) e matéria seca foram realizadas no Laboratório de Bromatologia do Departamento de Produção Animal da ESALQ/USP. Já os resultados referentes à proteína bruta foram determinados pelo Laboratório de Bioquímica do ITAL (Instituto de Tecnologia de Alimentos) em Campinas/SP, de acordo com a Association of Official Analytical Chemists (AOAC, 1980). A porcentagem do óxido crômico nas fezes e nas dietas foi determinada pela técnica analítica instrumental de fluorescência de raios X por dispersão de comprimento de onda (Nascimento Filho et al., 1997 e Zucchi \& Nascimento Filho, 1995). 


\subsubsection{Dete rminação da energia e da proteína digestíveis}

De posse dos resultados de energia bruta, matéria seca, proteína bruta e porcentagem de cromo das amostras, foram calculadas as médias para cada tratamento para todas as variáveis. Os valores médios em matéria seca foram, então, substituídos na seguinte equação (Thiré, 1986 e Veloso, 1980):

$$
\text { ND g dieta }=\text { NB g dieta }-\left(\text { NB g fezes x } \frac{\mathrm{Cr}_{2}}{\mathrm{Cr}_{2}} \frac{\mathrm{O}_{3}}{\mathrm{O}_{3}} \text { g dieta }\right),
$$

onde:

- $\quad$ ND g dieta $=$ nutriente digestível por grama de dieta;

- $\quad$ NB g fezes = nutriente bruto por grama de fezes;

- NB g dieta = nutriente bruto por grama de dieta.

A partir desta equação, puderam ser determinados os valores de energia e proteína digestíveis nas rações controle (basal) e teste, os quais também foram submetidos a uma outra equação (Veloso, 1980):

$$
\mathrm{ND} g=\mathrm{ND} g \text { basal }+\frac{(\mathrm{ED} g \text { teste }-\mathrm{ED} \mathrm{g} \text { basal })}{\% \text { inclusão do urucum }},
$$

onde:

- $\quad \mathrm{ND} g=$ nutriente digestível por grama de alimento teste;

- ND g basal = nutriente digestível por grama de ração basal;

- $\quad$ ND g teste $=$ nutriente digestível por grama de ração teste.

Deste modo, foram determinados os valores de energia e proteína digestíveis do resíduo de semente processada de urucum. 


\subsection{Ensaio de desempenho (Experimento II)}

No ensaio de desempenho (Experimento II), foram utilizados 40 animais, sendo 10 leitões mestiços (Landrace x Large White) e 30 leitões Seghers com idade e peso médio inicial de, respectivamente, 72 dias e $22,49 \mathrm{~kg}$. Os leitões foram distribuídos a quatro blocos de acordo com grupo genético e peso, num total de 20 parcelas (dois animais por parcela).

O experimento teve duração de 35 dias, durante a qual os animais receberam água e ração à vontade. As médias para as temperaturas mínimas e máximas, durante o Experimento II, foram de 19,1 e $30,7^{\circ} \mathrm{C}$, respectivamente. As medidas de temperatura foram tomadas diariamente por um termômetro localizado na mesma altura dos leitões e são apresentadas na Tabela A8 do Apêndice.

Para a avaliação do desempenho dos animais (consumo diário de ração, ganho diário de peso e conversão alimentar) foram realizadas, semanalmente, pesagens individuais e registros de consumo de ração para cada parcela. Diariamente, foi feita a higienização das instalações, assim como o fornecimento de ração.

\subsubsection{Tratamentos}

Foi testada a inclusão de níveis de 0,0, 2,5, 5,0, 7,5 e 10,0\% de resíduo de sementes processadas de urucum na dieta. As rações experimentais foram formuladas atendendo às exigências nutricionais preconizadas pelo NRC (1998), para animais em crescimento, sendo isoprotéicas, isoenergéticas e isolisínicas. Os principais componentes e suas composições básicas estão apresentados na Tabela 2. A composição percentual das rações experimentais, bem como os nutrientes calculados de cada uma delas estão apresentados na Tabela 3. 
Tabela 2. Composição dos principais componentes das rações experimentais (Experimento II).

\begin{tabular}{lccccc}
\hline Ingrediente & $\begin{array}{c}\text { Matéria } \\
\text { seca } \\
(\%)\end{array}$ & $\begin{array}{c}\text { Proteína } \\
\text { bruta } \\
(\%)\end{array}$ & $\begin{array}{c}\text { Prot. dig. } \\
\text { aparente } \\
(\%)\end{array}$ & $\begin{array}{c}\text { Energia } \\
\text { bruta } \\
(\mathrm{kcal} / \mathrm{g})\end{array}$ & $\begin{array}{c}\text { En. dig. } \\
\text { aparente } \\
(\mathrm{kcal} / \mathrm{g})\end{array}$ \\
\hline Milho & 87,10 & 8,19 & --- & 3.911 & --- \\
Farelo de soja & 88,75 & 47,00 & --- & 4.121 & --- \\
Resíduo de semente de urucum & 86,71 & 14,73 & 8,80 & 3.743 & 2.365 \\
\hline
\end{tabular}

Tabela 3. Composição percentual das rações experimentais e valores calculados do ensaio de desempenho (Experimento II).

\begin{tabular}{|c|c|c|c|c|c|}
\hline \multirow[b]{2}{*}{ Ingredientes } & \multicolumn{5}{|c|}{$\begin{array}{c}\text { Inclusão de resíduo } \\
\text { de semente processada de urucum }(\%)\end{array}$} \\
\hline & 0,0 & 2,5 & 5,0 & 7,5 & 10,0 \\
\hline Milho & 70,54 & 67,80 & 63,84 & 62,50 & 59,62 \\
\hline Farelo de soja & 25,86 & 25,57 & 25,54 & 24,95 & 24,70 \\
\hline Resíduo de semente de urucum & --- & 2,50 & 5,00 & 7,50 & 10,00 \\
\hline Óleo vegetal & 0,46 & 1,00 & 2,00 & 2,00 & 2,80 \\
\hline Calcário & 0,64 & 0,62 & 0,60 & 0,53 & 0,62 \\
\hline Fosfato bicálcico & 1,22 & 1,23 & 1,24 & 1,23 & 0,97 \\
\hline Sal & 0,28 & 0,28 & 0,28 & 0,29 & 0,29 \\
\hline Pré-mistura: & 1,00 & 1,00 & 1,50 & 1,00 & 1,00 \\
\hline Milho, veículo & $(0,70)$ & $(0,69)$ & $(0,51)$ & $(0,70)$ & $(0,70)$ \\
\hline BHT & $(0,10)$ & $(0,10)$ & $(0,10)$ & $(0,10)$ & $(0,10)$ \\
\hline Inerte (Filito) & $(0,00)$ & $(0,01)$ & $(0,69)$ & $(0,00)$ & $(0,00)$ \\
\hline Suplemento vitamínico $^{\mathrm{a}}$ & $(0,10)$ & $(0,10)$ & $(0,10)$ & $(0,10)$ & $(0,10)$ \\
\hline Suplemento mineral & $(0,10)$ & $(0,10)$ & $(0,10)$ & $(0,10)$ & $(0,10)$ \\
\hline \multicolumn{6}{|l|}{ Valores Calculados: } \\
\hline Energia digestível, kcal/kg & 3.400 & 3.400 & 3.400 & 3.400 & 3.419 \\
\hline Proteína bruta, \% & 18,00 & 18,00 & 18,00 & 18,00 & 18,00 \\
\hline Lisina, \% & 0,90 & 0,90 & 0,91 & 0,91 & 0,91 \\
\hline Cálcio, \% & 0,65 & 0,65 & 0,65 & 0,62 & 0,60 \\
\hline Fósforo total, \% & 0,55 & 0,55 & 0,55 & 0,55 & 0,50 \\
\hline \multicolumn{6}{|c|}{$\begin{array}{l}\text { a Quantidades supridas por kg de ração: vit. A, } 6000 \mathrm{UI} \text {; vit. } \mathrm{D}_{3}, 1500 \mathrm{UI} \text {; vit. E, } 15 \mathrm{UI} \text {; vit. } \mathrm{K}_{3}, 1,5 \mathrm{mg} \text {; } \\
\text { vit. } \mathrm{B}_{1}, 1,35 \mathrm{mg} \text {; vit. } \mathrm{B}_{2}, 4 \mathrm{mg} \text {; vit. } \mathrm{B}_{6}, 2 \mathrm{mg} \text {; vit. } \mathrm{B}_{12}, 20 \mathrm{mg} \text {; ácido nicotínico, } 20 \mathrm{mg} \text {; ácido fólico, } 0,6 \\
\text { mg; biotina, } 0,8 \mathrm{mg} \text {; ácido pantotênico, } 9,35 \mathrm{mg} \text {; selênio } 0,3 \mathrm{mg} \text {. }\end{array}$} \\
\hline
\end{tabular}




\subsubsection{Delineamento experimental}

Utilizou-se do delineamento em blocos casualizados com cinco tratamentos (níveis de inclusão de 0,0, 2,5, 5,0, 7,5 e 10,0\% de resíduo de semente de urucum), quatro repetições por tratamento, dois animais (um macho castrado e uma fêmea) por unidade experimental, totalizando 20 unidades experimentais. Os animais foram distribuídos nos blocos de acordo com o peso e o grupo genético.

\subsubsection{Análise dos dados}

Foram analisadas as seguintes variáveis: consumo diário de ração (CDR), ganho diário de peso (GDP) e conversão alimentar (CA). Todos os dados obtidos foram submetidos à análise de variância PROC GLM do SAS (Statistical Analysis System, 1993). Além disso, os graus de liberdade do fator porcentagem de resíduo de semente

processada de urucum na ração foram decompostos em seus componentes individuais de regressão, pelos polinômios ortogonais, para as variáveis de desempenho. 


\section{RESULTADOS E DISCUSSÃO}

\subsection{Ensaio de digestibilidade (Experimento I)}

Os resultados de digestibilidade do resíduo de sementes processadas de urucum para suínos em crescimento são apresentados na Tabela 4 e 5. Outros valores mais detalhados deste ensaio são apresentados nas Tabelas A1, A2 e A3 do Apêndice.

Tabela 4. Resultados do ensaio de digestibilidade aparente da energia bruta do resíduo de semente processada de urucum (Experimento I)

\begin{tabular}{lccc}
\hline Alimento & $\begin{array}{c}\text { Energia } \\
\text { bruta } \\
(\mathrm{kcal} / \mathrm{kg})\end{array}$ & $\begin{array}{c}\text { En. dig. } \\
\text { aparente } \\
(\mathrm{kcal} / \mathrm{kg})\end{array}$ & $\begin{array}{c}\text { Coef. dig. } \\
\text { aparente } \\
(\%)\end{array}$ \\
\hline Resíduo de urucum & 3.740 & 2.365 & 63,2 \\
\hline
\end{tabular}

Tabela 5. Resultados do ensaio de digestibilidade aparente da proteína bruta do resíduo de semente processada de urucum (Experimento I)

\begin{tabular}{lccc}
\hline Alimento & $\begin{array}{c}\text { Proteína } \\
\text { bruta } \\
(\%)\end{array}$ & $\begin{array}{c}\text { Prot. dig. } \\
\text { aparente } \\
(\%)\end{array}$ & $\begin{array}{c}\text { Coef. dig. } \\
\text { aparente } \\
(\%)\end{array}$ \\
\hline Resíduo de urucum & 14,73 & 8,80 & 59,7 \\
\hline
\end{tabular}


Como se pode observar, nenhum dos nutrientes estudados no resíduo de semente de urucum possui um alto coeficiente de digestibilidade aparente. A energia bruta do resíduo de semente de urucum, determinada neste ensaio é de $3.740 \mathrm{kcal} / \mathrm{kg}$. No entanto, o coeficiente de digestibilidade aparente da energia é de 63,2\%, proporcionando o valor de energia digestível aparente de $2.365 \mathrm{kcal} / \mathrm{kg}$. Esse valor, entretanto, é semelhante ao de outros alimentos alternativos, utilizados na alimentação de suínos, que possuem composições bromatológicas muito próximas, como é o caso do farelo de trigo, $2.367 \mathrm{kcal} / \mathrm{kg}$, e do farelo de arroz desengordurado, $2.531 \mathrm{kcal} / \mathrm{kg}$ (Rostagno et al., 2000).

O resíduo de sementes de urucum não pode ser visto como uma excelente fonte de energia, ao menos diante dos resultados encontrados no presente estudo, pois seu valor de energia digestível aparente $(2.365 \mathrm{kcal} / \mathrm{kg})$ é significativamente inferior aos valores de energia digestível de cereais considerados alimentos energéticos. Além do milho, alguns dos principais cereais energéticos são o sorgo de baixo tanino, o triticale e o trigo, os quais possuem valores médios de energia digestível de 3.794 (Ferreira et al., 1997), 3.236 (Furlan at al., 1999 e Radecki \& Miller, 1990) e $3.300 \mathrm{kcal} / \mathrm{kg}$ (Lima \& Viola, 2001), respectivamente. O principal entrave está realmente na digestibilidade da energia do alimento, conforme indicado anteriormente.

Assim, fica evidenciado que o resíduo de urucum, embora possuindo altos níveis de energia bruta, este nutriente é muito pouco aproveitado pelo suíno. Alguns autores (Ferreira et al., 1997; Fialho et al., 1986; Holden \& Zimmerman, 1993 e Lekule et al., 1990) observaram uma relação inversa entre o conteúdo de fibra bruta do alimento e a sua digestibilidade. Esta pode ser uma possível justificativa para a baixa digestibilidade da energia do resíduo de semente de urucum, pois este alimento possui 12,5-14,4\% de fibra bruta (Tonani, 1995 e Wurts \& Torreblanca, 1983).

Os teores de fibra bruta são de 8,1-11,0\% para o farelo de trigo (EMBRAPA/CNPSA, 1991; Fialho et al., 1986; Rostagno et al., 2000 e Zardo \& Lima, 1999) e de 9,8-12,0\% para o farelo de arroz desengordurado (EMBRAPA/CNPSA, 1991; Lima et al., 1999; Rostagno et al., 2000; Santos, 1971 e Zardo \& Lima, 1999). As semelhanças do resíduo de semente de urucum para com o farelo de trigo e o farelo de 
arroz desengordurado não se restringem somente ao conteúdo de fibra bruta. $\mathrm{O}$ farelo de trigo e o farelo de arroz desengordurado possuem valores de energia digestível para suínos que variam, respectivamente, entre 2.103 e 2.623 kcal/kg (Albino \& Silva, 1996; NRC, 1998 e Rostagno et al., 2000) e 2.243-2.608 kcal/kg (EMBRAPA/CNPSA, 1991; Lima et al., 1999; Rostagno et al., 2000; Santos, 1971 e Zardo \& Lima, 1999), muito próximos ao valor de energia digestível do resíduo de semente de urucum (2.365 $\mathrm{kcal} / \mathrm{kg})$.

Já em relação à proteína bruta e sua digestibilidade, as comparações podem ser feitas com os mesmos alimentos, uma vez que o valor de proteína bruta encontrado para o resíduo de semente urucum é muito próximo $(14,7 \%)$ aos valores de de 14-16,7\% para o farelo de trigo (EMBRAPA/CNPSA, 1991; Fialho et al., 1986; Rostagno et al., 2000 e Zardo \& Lima, 1999) e de 14-17,7\% para o farelo de arroz desengordurado (EMBRAPA/CNPSA, 1991; Rostagno et al., 2000; Santos, 1971 e Zardo \& Lima, 1999). O farelo de trigo possui, em média, o coeficiente de digestibilidade de sua proteína de $75 \%$ para suínos (Rostagno et al., 2000), enquanto que o valor encontrado para o resíduo de semente de urucum foi de 59,7\%. Esse valor continua sendo baixo, quando comparado ao coeficiente de digestibilidade de proteína do farelo de arroz desengordurado que é, em média, de $73 \%$ (Rostagno et al., 2000).

A baixa digestibilidade aparente da proteína e da energia do resíduo de semente de urucum não deve ser consequência apenas do alto conteúdo de fibra bruta. Outros fatores, como a qualidade da fibra presente nesta fração, podem estar afetando a digestibilidade destes nutrientes, uma vez que os teores de fibra bruta no resíduo de semente de urucum são, relativamente, próximos aos encontrados no farelo de trigo e no farelo de arroz desengordurado, como já mencionado. No entanto, a qualidade fisiológica da fibra daqueles alimentos, particularmente da fibra bruta do farelo de trigo, deve ser superior a de outros alimentos fibrosos.

A qualidade da fibra dietética do alimento está diretamente ligada aos teores de fibra em detergente neutro (FDN) e fibra em detergente ácido (FDA) presente nesta fração. Estes, por sua vez, estão também, diretamente correlacionados com a digestibilidade dos nutrientes, principalmente em alimentos fibrosos (Bell \& Keith, 
1989, 1988; Gomes, 1996 e Gomes et al., 1999). Rostagno et al.(2000) relatou que o farelo de trigo possui 40,54\% de FDN, enquanto que Tonani (1995) obteve um valor de $36,75 \%$ para o resíduo de semente de urucum. Apesar da pouca diferença na porcentagem de FDN, os alimentos comparados possuem uma maior diferença no teor de fibra em detergente ácido (FDA), que representa a fração indigestível da fibra dietética e que pode, também, influir na digestibilidade dos nutrientes (Gomes, 1996). Os valores são de 11,26\% para o farelo de trigo (Rostagno et al., 2000) e de 20,23\% para resíduo de semente de urucum (Tonani, 1995).

Portanto, sabe-se que além do maior conteúdo de fibra bruta, o resíduo de semente de urucum deve possuir uma fibra de baixa qualidade. Tal suposição é importante e pode, possivelmente, justificar os menores valores de energia e proteína digestíveis encontrados para este alimento, quando comparado com similares.

\subsection{Ensaio de desempenho (Experimento II)}

Os valores médios de cada parcela para as variáveis de consumo diário de ração (CDR, kg), ganho diário de peso (GDP, kg) e conversão alimentar (CA) são apresentados na Tabela 6, 7 e 8, respectivamente. As médias de cada tratamento para essas variáveis, assim como os coeficientes de variação são apresentados na Tabela 9. Os valores dos pesos vivos dos leitões e das variáveis de desempenho dos animais obtidos semanalmente, assim como as temperaturas mínimas e máximas diárias, são apresentados nas Tabelas A4, A5, A6, A7 e A8 do Apêndice. 
Tabela 6. Valores médios de consumo diário de ração (CDR, $\mathrm{kg}$ ) dos leitões, durante o período experimental de 35 dias (Experimento II).

\begin{tabular}{ccccccc}
\hline \multirow{2}{*}{ Bloco } & \multicolumn{5}{c}{ Níveis de inclusão de RSPU ${ }^{\mathrm{a}}$ na dieta $(\%)$} & \multirow{2}{*}{ Média } \\
\cline { 2 - 5 } & 0,0 & 2,5 & 5,0 & 7,5 & 10,0 & 1,892 \\
1 & 1,794 & 1,707 & 2,113 & 2,010 & 1,835 & 1,842 \\
2 & 1,853 & 1,908 & 1,857 & 1,976 & 1,616 & 1,682 \\
3 & 1,609 & 1,569 & 1,552 & 1,745 & 1,935 & 2,105 \\
4 & 2,241 & 2,211 & 2,184 & 1,843 & 2,047 & 1,880 \\
\hline
\end{tabular}

${ }^{a}$ Resíduo de semente processada de urucum.

Tabela 7. Valores médios de ganho diário de peso (GDP, kg) dos leitões, durante o período experimental de 35 dias (Experimento II).

\begin{tabular}{ccccccc}
\hline \multirow{2}{*}{ Bloco } & \multicolumn{5}{c}{ Níveis de inclusão de RSPU ${ }^{\mathrm{a}}$ na dieta $(\%)$} & \multirow{2}{*}{ Média } \\
\cline { 2 - 5 } & 0,0 & 2,5 & 5,0 & 7,5 & 10,0 & 0,886 \\
2 & 0,796 & 0,791 & 1,011 & 0,954 & 0,879 & 0,872 \\
3 & 0,921 & 0,881 & 0,850 & 0,939 & 0,769 & 0,804 \\
4 & 0,860 & 0,763 & 0,710 & 0,759 & 0,926 & 0,975 \\
Média & 0,951 & 1,033 & 0,987 & 0,890 & 1,014 & 0,884 \\
\hline
\end{tabular}

${ }^{a}$ Resíduo de semente processada de urucum.

Tabela 8. Valores médios de conversão alimentar (CA) dos leitões, durante o período experimental de 35 dias (Experimento II).

\begin{tabular}{ccccccc}
\hline \multirow{2}{*}{ Bloco } & \multicolumn{5}{c}{ Níveis de inclusão de RSPU $^{\mathrm{a}}$ na dieta $(\%)$} & \multirow{2}{*}{ Média } \\
\cline { 2 - 5 } & 0,0 & 2,5 & 5,0 & 7,5 & 10,0 & 2,139 \\
2 & 2,255 & 2,157 & 2,089 & 2,107 & 2,089 & 2,114 \\
3 & 2,011 & 2,165 & 2,184 & 2,105 & 2,103 & 2,101 \\
4 & 1,871 & 2,057 & 2,186 & 2,300 & 2,090 & 2,159 \\
Média & 2,355 & 2,140 & 2,213 & 2,071 & 2,018 & 2,128 \\
\hline
\end{tabular}

${ }^{\mathbf{a}}$ Resíduo de semente processada de urucum. 
Tabela 9. Valores médios dos tratamentos para consumo diário de ração (CDR, kg), ganho diário de peso (GDP, kg) e conversão alimentar (CA), durante o período experimental de 35 dias (Experimento II).

\begin{tabular}{ccccccc}
\hline \multirow{2}{*}{ Variável } & \multicolumn{4}{c}{ Níveis de inclusão de RSPU ${ }^{\mathrm{a}}$ na dieta (\%) } & CV $^{\mathrm{b}}$ \\
\cline { 2 - 6 } & 0,0 & 2,5 & 5,0 & 7,5 & 10,0 & $\%$ \\
\hline CDR & 1,874 & 1,849 & 1,927 & 1,894 & 1,858 & 9,45 \\
GDP & 0,882 & 0,867 & 0,890 & 0,886 & 0,897 & 10,16 \\
CA & 2,123 & 2,130 & 2,168 & 2,146 & 2,075 & 5,91 \\
\hline
\end{tabular}

${ }^{a}$ Resíduo de semente processada de urucum.

${ }^{b}$ Coeficiente de variação.

Analisando-se os dados pelo PROC GLM (SAS, 1993), não foi observada $(\mathrm{P}>0,05)$ nenhuma tendência (linear, quadrática, cúbica ou de quarto grau), para as variáveis de desempenho. Quando comparadas as médias dos tratamentos para cada variável pelo teste de Tukey, não foi detectada nenhuma diferença significativa $(P>0,05)$ entre os tratamentos.

Fialho et al. (1986), utilizando níveis crescentes (0, 10, 20 e 30\%) de farelo de trigo, em dietas desiguais em energia digestível (3.837, 3.692, 3.659 e 3.535 $\mathrm{kcal} / \mathrm{kg}$, respectivamente), não encontraram diferenças no desempenho de suínos em crescimento. Ferreira et al. (1984) também não observaram alterações no desempenho de suínos em crescimento alimentados com dietas contendo até $25 \%$ de farelo de arroz desengordurado e com níveis decrescentes de energia digestível na dieta.

Santos (1971), utilizando níveis crescentes (0, 15, 30 e 45\%) de inclusão de farelo de arroz desengordurado, observou uma redução na energia digestível (3.380, $3.098,2.815,2.532 \mathrm{kcal}$, respectivamente) das dietas. Como resultado, houve redução linear do desempenho de suínos em crescimento, a medida que se aumentava a porcentagem de farelo de arroz desengordurado na dieta. Outros autores encontraram resultados muito semelhantes, havendo redução no desempenho de suínos em crescimento alimentados com dietas contendo até 80\% (Borin Jr. et al., 1988) ou 25 a $75 \%$ (Ferreira et al., 1984) de farelo de arroz desengordurado. 
Assim, pode-se observar que a porcentagem de inclusão do ingrediente e a consequente variação da energia digestível da dieta podem influenciar no desempenho de suínos alimentados com alimentos como o farelo de trigo e o farelo de arroz desengordurado. Por outro lado, os resultados do presente estudo podem ser justificados, já que as dietas experimentais eram isoenergéticas (em energia digestível), isoprotéicas e isolisínicas.

Ferreira et al. (1992) alertam para o fato de que, normalmente, os alimentos alternativos trazem prejuízos ao desempenho dos animais, devido a problemas de palatabilidade, redução de consumo e deficiência de aminoácidos. No entanto, há indicações de que o resíduo de semente de urucum na dieta não deve ter causado tais problemas, pois não houve diferença nem no consumo, e nem no ganho de peso dos leitões submetidos aos diferentes tratamentos.

Há, também, indicações (Morrison et al., 1991) de que o resíduo de semente de urucum poderia elevar a taxa de glicemia dos animais. Este processo, possivelmente, não tenha ocorrido neste estudo, pois, caso contrário, deveria ocorrer uma resposta homeostática de redução de consumo, devido às altas taxas de glicemia no sangue dos animais que consumiram o resíduo de semente de urucum.

Em relação à variável $\mathrm{CA}$, pôde-se notar uma discreta melhora numérica à medida que se aumentou o nível de inclusão do resíduo de semente de urucum na dieta. Alguns pesquisadores (Cáceres et al., 1998; Chadriandy et al., 1999 e Irobi et al., 1996), recentemente, confirmaram atividades antibacterianas de eficiência variável em culturas de microrganismos como: Pseudomonas aeruginosa, Salmonella typhi, Staphylococcus aureos, Candida albicans, Cryptococcus neoformans, Aspergillus flavus. A eficiência da ação bactericida varia de acordo com o tipo de microrganismo, sendo as bactérias gram positivas, como os estreptococos e estafilococos, as mais susceptíveis (Irobi et al., 1996). A possível inibição destes microrganismos, de alguma forma, pode estar colaborando no aumento da eficiência de utilização do alimento pelos animais. Esta suposição pode estar ligada a algum tipo de propriedade promotora de crescimento, ou antibiótica, provavelmente presente nas sementes de urucum. 
O resíduo de semente processada de urucum deve ser melhor estudado na alimentação de suínos, sendo que os resultados deste estudo são, praticamente, os primeiros dados obtidos em pesquisas científicas sobre este subproduto. Experimentos com maiores níveis de inclusão do resíduo de semente de urucum devem ser realizados, já que a inclusão de até $10 \%$ de resíduo de semente de urucum na dieta não alterou o desempenho dos animais. 


\section{CONCLUSÃO}

O resíduo de semente processada de urucum é um alimento que apresenta coeficientes de digestibilidade para energia e proteína de, respectivamente, 63,2 e 59,7\% para suínos em crescimento, proporcionando $2.365 \mathrm{kcal} / \mathrm{kg}$ de energia digestível e 8,8 \% de proteína digestível.

Em relação a uma dieta padrão de milho e farelo de soja, desde que mantidas as dietas isoenergéticas (em energia digestível), isoprotéicas e isolisínicas, o resíduo de semente processada de urucum pode ser incluído até o nível de $10 \%$, sem influenciar o desempenho de suínos em crescimento. 


\section{REFERÊNCIAS BIBLIOGRÁFICAS}

ALBINO, L.F.T.; SILVA, M.A. Valores nutritivos de alimentos para aves e suínos determinados no Brasil. In: SIMPÓSIO INTERNACIONAL SOBRE EXIGÊNCIAS NUTRICIONAIS DE AVES E SUÍNOS, Viçosa, 1996. Anais. Viçosa: UFV, 1996. p.303-318.

ASSOCIATION OF OFFICIAL ANALYTICAL CHEMISTS. Official methods of analysis. 13.ed. Washington, 1980. 1025p.

BAELMANS, R.; DEHARO, E.; BOURDY, G.; MUÑOZ, V.; QUENEVO, C.; SAUVAIN, M.; GINSBURG, H. A search for natural bioactive compounds in Bolivia through a multidisciplinary approach. Part IV. Is a new haem polymerisation inhibition test pertinent for the detection of antimalarial natural products? Journal of Ethnopharmacology, v.73, p.271-275, 2000.

BELL. M.J.; KEITH, M.O. Effects of barley hulls, dietary protein level and weight of pig on digestibility of canola meal fed to finishing pigs. Canadian Journal of Animal Science, v.68, n.2, p.493-502, 1988.

BELL, M.J.; KEITH, M.O. Factors affecting the digestibility by pigs of energy and protein in wheat, barley and sorghum diets supplemented with canola meal. Animal Feed Science, v.24, n.1, p.253-265, 1989.

BORIN JUNIOR, H.; GAI, J.N.; SILVEIRA, J.C.G.L. Efeitos da adição de diferentes níveis de farelo de arroz desengordurado em rações para suínos nas fases de crescimento e terminação. Revista da Sociedade Brasileira de Zootecnia, v.17, n.6, p.552-562, 1988. 
BROUSSALIS, A.M.; FERRARO, G.E.; MARTINO, V.S.; PINZÓN, R.; COUSSIO, J.D.; ALVAREZ, J.C. Argentine plants as potencial source of inseticidal compounds. Journal of Ethnopharmacology, v.67, p.219-223, 1999.

CÁCERES, A.; LÓPEZ, B.; GONZÁLEZ, S.; BERGER, I.; TADA, I.; MAKI, J. Plants used in Guatemala for treatment of protozoal infections. I. Screening of activity to bacteria, fungi and american trypanosomes of 13 natives plants. Journal of Ethnopharmacology, v.62, p.195-202, 1998.

CARVAlHO, P.R.N. Annatto: technological advances and perspectives. Archivos Latinoamericanos de Nutrición, v.49, n.3, p.71s-73s, sep 1999.

CATÁLOGO RURAL. Urucum. http://www.agrov.com/vegetais/fru/urucum.html, 17 abr. 2001.

CHARIANDY, C.M.; SEAFORTH, C.E.; PHELPS, R.H.; POLLARD, G.V.; KHAMBAY, B.P.S. Screening of medicinal plants from Trinidad and Tobago for antimicrobial and inseticidal properties. Journal of Ethnopharmacology, v.64, p.265-270, 1999.

EMPRESA BRASILEIRA DE PESQUISA AGROPECUÁRIA - CENTRO NACIONAL DE PESQUISA DE SUÍNOS E AVES. Tabela de composição química e valores energéticos de alimentos para suínos e aves. Concórdia: EMBRAPA-CNPSA, 1991. 97p.

FAO. Quarterly bulletin of statistics. Roma: FAO, 2001. 107p.

FERREIRA, A.S.; LIMA, G.J.M.M.; ZANOTTO, D.L.; BASSI, L.J. Triticale como alimento alternativo para suínos em crescimento e terminação. Revista da Sociedade Brasileira de Zootecnia, v.21, n.2, p.300-308, 1992. 
FERREIRA, C.L.B; NICOLAIEWSKY, S; PRATES, E.R.; LÓPES, J. Níveis crescentes de farelo de arroz desengordurado em rações para suínos em crescimento e terminação. Revista da Sociedade Brasileira de Zootecnia, v.13, n.3, p.426-432, 1984.

FERREIRA, E.R.A.; FIALHO, E.T.; TEIXEIRA, A.S.; LIMA, J.A.F.; GONÇALVES, T.M. Avaliação da composição química e determinação de valores energéticos e equações de predição de alguns alimentos para suínos. Revista Brasileira de Zootecnia, v.26, n.3, p.514-523, 1997.

FIALHO, E.T.; GOMES, P.C.; BELLAVER, C.; PROTAS, J.F.S.; COSTA, V. Níveis de farelos de trigo em rações de suínos em crescimento e terminação. Pesquisa Agropecuária Brasileira, v.21, n.6, p.665-671, 1986.

FREIXA, B.; VILA, R.; VARGAS, L.; LOZANO N.; ADZET, T.; CANIGUERAL, S. Screening for antifungal activity of nineteen latin american plants. Phytoterapy Research, v.12, p.427-430, 1998.

FURLAN, A.C.; MIKAMI, F.; MOREIRA, I.; SCAPINELLO, C.; MURAKAMI, A.E. Uso do triticale (Triticum turgidosecale) na alimentação de suínos em crescimento (25-60 kg). Revista Brasileira de Zootecnia, v.28, n.5, p.1042-1049, 1999.

GESSULLI AGRIBUSINESS. Anuário' 2001 da suinocultura industrial. Porto Feliz, 2001. 70p.

GOMES, J.D.F. Efeitos do incremento de fibra em detergente neutro, sobre parâmetros de desempenho, de digestibilidade dos componentes dietéticos e da morfologia intestinal das marrãs. Botucatu, 1996. 110p. Tese (Doutorado) - Faculdade de Medicina Veterinária e Zootecnia, Universidade Estadual Paulista "Júlio de Mesquita Filho". 
GOMES, J.D.F.; GOMIDE, C.A; FUKUSHIMA, R.S; FAGUNDES, A.C.F.; GROSSKLAUS, C.; PUTRINO, S.M.; UTIYAMA, C.E.; SILVA, G.T.N.; SOUZA, L.W.O.; OETTING, L.L. Efeitos do Incremento de Fibra em Detergente Neutro (FDN) Sobre a Digestibilidade de Suínos em Fase de Crescimento-Terminação. In: CONGRESSO BRASILEIRO DE VETERINÁRIOS ESPECIALISTAS EM SUÍNOS, 9., Belo Horizonte, 1999. Resumos. Belo Horizonte: MINASCENTRO, 1999. p.449.

HERNANDEZ, C.P.; RUSIG, O. Extrato de urucum (Bixa orellana L.) obtido utilizando álcool etílico como solvente. Arquivos de Biologia e Tecnologia, v.35, n.1, p.6374, mar 1992.

HOLDEN, P.J.; ZIMMERMAN, D.R. Utilization of cereal grain byproduct in feeding swine. In: MILLER, E.R.; ULLREY, D.E; LEWIS, A.J.; (Ed.) Swine nutrition. Stonehan: Butterworth-Heineman, 1991. cap.36, p.585-593.

IROBI, O.N.; MOO YOUNG, M.; ANDERSON, W.A. Antimicrobial activity of Annatto (Bixa orellana L.) extract. International Journal of Pharmacognosy, v.34, n.2, p.87-90, May 1996.

LEKULE, F.P.; JORGENSEN, H.; FERNANDEZ, J.A.; JUST, A. Nut ritive value of some tropical feedstuffs for pigs. Chemical composition, diegestibilty and metabolizable energy content. Animal Feed Science and Technology, v.28, n.1-2, p.91-101, Feb 1990.

LENTZ, D.L.; CLARK, A.M.; HUFFORD, C.D.; GRIMES, B.M.; PASSREITER, C.M.; CORDERO, J.; IBRAHIMI, O.; OKUNADE, A.L. Antimicrobial properties of honduran medicinal plants. Journal of Ethnopharmacology, v.63, p.253-263, 1998. 
LIMA, G.J.M.M.; VIOLA, E.S. Ingredientes energéticos: trigo e triticale na alimentação animal. In: SIMPÓSIO SOBRE INGREDIENTES NA ALIMENTAÇÃO ANIMAL, Campinas, 2001. Anais. Campinas: IAC, 2001. p.33-76.

LIMA, G.J.M.M.; MARTINS, R.; ZANOTTO, D.L.; BRUM, P.A.R. Composição Química e Valores de Energia de Subprodutos do Beneficiamento do Arroz. In: CONGRESSO BRASILEIRO DE VETERINÁRIOS ESPECIALISTAS EM SUÍNOS, 9., Belo Horizonte, 1999. Resumos. Belo Horizonte: MINASCENTRO, 1999. p.445.

MIYADA, V. S. A levedura seca na alimentação de suínos: estudos adicionais sobre o seu valor protéico e vitamínico. Piracicaba, 1987. 159p. Tese (Livre Docência) Escola Superior de agricultura Luiz de Queiroz, Universidade de São Paulo.

MIYADA, V.S.; MENTEN, J.F.M.; BENATI, M. Utilização de alimentos alternativos na formulação de rações para suínos. In: MINI SIMPÓSIO DO COLÉGIO BRASILEIRO DE NUTRIÇÃO ANIMAL, 10., Valinhos, 1993. Anais. p.117-150.

MOREIRA, I. Valor nutritivo e utilização de milho e soja integral processados a calor na alimentação de leitões. Viçosa, 1993. 145p. Tese (Doutorado) - Universidade Federal de Viçosa.

MORRISON, E.; THOMPSON, H.; PASCOE, K.; WEST, M.; FLETCHER, C. Extraction of na hyperglycemic principle from the Annatto (Bixa orellana), a medicinal plant in the West-Indies. Tropical and Geographical Medicine, v.43, n.1-2, p.184-188, Jan-Apr 1991.

MYER, R.O.; BRENDEMUHL, J.H.; BARNETT, R.D. Crystaline lysineand threonine supplementation of soft red winter wheat or triticale, low protein diets for growingfinishing pigs swine. Journal of Animal Science, v.74, n.3, p.577-583, 1996. 
NASCIMENTO FILHO, V.F.; ABDALA, A.L.; KORNDORFER, C.M.; NAVARRO, A.A.; BUENO, I.C.S. Sensibilidades analíticas de diferentes modos de excitação em fluorescência de raios $\mathrm{X}$ para medida de traçadores em fezes de animais. In: ENCONTRO CIENTÍFICO DOS PÓS GRADUANDOS DO CENA/USP, Piracicaba, 1997. Resumos. Piracicaba: CENA, 1997. p.69.

NATIONAL RESEARCH COUNCIL. Subcommittee on Swine Nutrition. Committee on Animal Nutrition. Nutrient Requeriments of Swine. 10.ed. Washington: National Academy Press, 1998. 189p.

OLIVEIRA, V.P. Agroindústria do urucum no sudeste do Brasil. In: SIMPÓSIO INTERNACIONAL DO URUCUM, 1., Campinas, 1991. Anais. Campinas: ITAL;IAC;IAL, 1991. p.163-164.

OTERO, R.; NÚÑEZ, V.; JIMÉNEZ, S.L.; FONNEGRA, R.; OSORIO, R.G.; GARCÍA, M.E.; DÍAZ, A. Snakebites and ethnobotany in the northwest region of Colombia. Part II. Neutralization of ethal and enzymatic effects of Bothrops atrox venon. Journal of Ethnopharmacology, v.71, p.505-511, 2000a.

OTERO, R.; NÚÑEZ, V.; BARONA, J.; FONNEGRA, R.; JIMÉNEZ, S.L.; OSORIO, R.G.; SALDARRIAGA, M.; DÍAZ, A. Snakebites and ethnobotany in the northwest region of Colombia. Part II. Neutralization of haemorragic effect of Bothrops atrox venon. Journal of Ethnopharmacology, v.73, p.233-241, 2000 b.

PASCHOINI, J.R. Nutricum: a proteína e o corante natural do urucum. São Sebastião do Paraíso: Paschoini Agro Ltda, 2000. 7p.

PIMENTEL, F.A. Avaliação de métodos de obtenção e da estabilidade de pigmentos de sementes de urucum (Bixa orellana L.). Viçosa, 1995. 132p. Dissertação (Mestrado) - Universidade Federal de Viçosa. 
RADECKI, S.V.; MILLER, E.R. Triticale. In: THACKER, P.A.; KIRKWOOD, R.N. (ed.) Nontraditional feed sources for use in swine production. Stonehan: Butterworth-Heineman, 1990. cap.48, p.493-500.

RODRIGUES, J.P.F. Análise de isoenzimas em progênies de meio-irmãos de urucum (Bixa orellana L.). Viçosa, 1995. 76 p. Dissertação (Mestrado) - Universidade Federal de Viçosa.

ROSTAGNO, H.S.; ALBINO, L.F.T.; DONZELE, J.L.; GOMES, P.C.; FERREIRA, A.S.; OLIVEIRA, R.F.; LOPES, D.C. Tabelas brasileiras para aves e suínos: composição de alimentos e exigências nutricionais. Viçosa: Universidade de Viçosa, 2000. 141p.

SANTOS, C.A. Níveis de farelo de arroz desengordurado para suínos em crescimento e engorda. Viçosa, 1971. 57p. Dissertação (Mestrado) - Universidade Federal de Viçosa.

SILVA, J.H.V.; ALBINO, L.F.T.; GODÓI, M.J.S. Efeito do extrato de urucum na pigmentação de gema de ovos. Revista Brasileira de Zootecnia, v.29, n.5, p.1435$1439,2000$.

STATISTICAL ANALYSIS SYSTEM INSTITUTE. SAS user's guide: statistics. Carry, 1993. 155p.

THIRÉ, M.C. Valores energéticos e digestibilidade ileal total de aminoácidos em alimentos brasileiros para suínos. Viçosa, 1986. 65p. Tese (Mestrado) Universidade Federal de Viçosa. 
TONANI, F. Estudo do valor nutritivo da semente do urucum (Bixa orellana $\mathbf{L}$.) e seu efeito sobre o desempenho de bovinos de corte. Jaboticabal: FCAV/UNESP, Depto. de Zootecnia de Não Ruminantes, 1995. 11p. (Parecer técnico apresentado à Paschoini Agro Ltda, São Sebastião da Grama).

TORRES, C.L. Urucum: desponta uma grande alternativa agrícola. Balde Branco, v.21, n.261, p.25-27, jul.1986.

VELOSO, J.A.F. Avaliação química e biológica do melaço em pó para suínos. Viçosa, 1980. 77p. Tese (Doutorado) - Universidade Federal de Viçosa.

WURTS, M.L.; TORREBLANCA, R.A. Analisis de la semilla Bixa orellana L. (Achiote) y del desecho generado en la extraccion de sus pigmentos. Archivos Latinoamericanos de Nutrición, v.33, n.3, p.606-619, 1983.

ZARDO, A.O.; LIMA, G.J.M.M. Alimentos para suínos. Boletim Informativo da Pesquisa Embrapa Suínos e Aves e da Extensão Rural, v. 8, n.12, p.1-71, dez 1999.

ZUCCHI, O.L.A.D.; NASCIMENTO FILHO, V.F. Caracterização qualitativa e quantitativa de elementos, pela técnica de fluorescência de raios $\mathrm{X}$, em suplementos minerais para animais. I. Dispersão de comprimento de onda. Pesquisa Agropecuária Brasileira, v.30, n.12, p.1427-1439, dez.1995. 
APÊNDICE 
Tabela A1. Cálculo de restrição alimentar durante o período de coleta do ensaio de digestibilidade (Experimento I).

\begin{tabular}{ccccccc}
\hline Tratamento & $\begin{array}{c}\text { Peso } \\
(\mathrm{kg})\end{array}$ & $\begin{array}{c}\text { Peso } \\
\text { metabólico }^{\mathrm{a}}\end{array}$ & $\begin{array}{c}\text { Consumo } \\
\text { diário } \\
(\mathrm{kg})\end{array}$ & $\begin{array}{c}\text { Índice } \\
\text { individual }^{\mathrm{b}}\end{array}$ & $\begin{array}{c}\text { Índice } \\
\text { geral }\end{array}$ & $\begin{array}{c}\text { Consumo }^{\text {restrito }} \\
(\mathrm{Kg})\end{array}$ \\
\hline Basal 1 & 40,5 & 16,05 & 1,695 & 0,1056 & 0,0779 & 1,250 \\
Basal 2 & 40,8 & 16,14 & 1,490 & 0,0923 & 0,0779 & 1,260 \\
Basal 3 & 37,9 & 15,27 & 1,610 & 0,1054 & 0,0779 & 1,190 \\
Basal 4 & 40,8 & 16,14 & 1,680 & 0,1040 & 0,0779 & 1,260 \\
Teste 1 & 43,5 & 16,93 & 1,805 & 0,1066 & 0,0779 & 1,320 \\
Teste 2 & 38,3 & 15,39 & 1,250 & 0,0812 & 0,0779 & 1,200 \\
Teste 3 & 38,2 & 15,36 & 1,545 & 0,1005 & 0,0779 & 1,200 \\
Teste 4 & 33,9 & 14,04 & 1,095 & 0,0779 & 0,0779 & 1,090 \\
\hline
\end{tabular}

${ }^{a}$ Peso metabólico $=$ Peso vivo ${ }^{0,75}$

${ }^{\mathrm{b}}$ Índice $=$ Consumo $/$ Peso metabólico

${ }^{\mathrm{c}}$ Consumo restrito $=$ Peso metabólico $\mathrm{x}$ Índice geral 
Tabela A2. Composição das amostras de fezes, ração basal, ração teste e urucum (Experimento I).

\begin{tabular}{ccccc}
\hline Amostra & $\begin{array}{c}\text { Matéria seca } \\
(\%)\end{array}$ & $\begin{array}{c}\text { Energia bruta } \\
(\mathrm{kcal} / \mathrm{g})\end{array}$ & $\begin{array}{c}\text { Proteína bruta } \\
(\%)\end{array}$ & $\begin{array}{c}\mathrm{Cr}_{2} \mathrm{O}_{3} \\
(\%)\end{array}$ \\
\hline Basal 1 (fezes) & 90,96 & 3919,51 & 17,46 & 2,715 \\
Basal 2 (fezes) & 90,67 & 3985,21 & 17,01 & 2,933 \\
Basal 3 (fezes) & 91,95 & 4082,77 & 16,09 & 2,494 \\
Basal 4 (fezes) & 91,45 & 3860,96 & 17,27 & 2,874 \\
Média & 91,26 & 3962,11 & 16,95 & 2,754 \\
Teste 1 (fezes) & 91,93 & 4164,44 & 17,47 & 2,014 \\
Teste 2 (fezes) & 90,96 & 4238,83 & 16,57 & 2,180 \\
Teste 3 (fezes) & 91,70 & 4286,98 & 18,36 & 2,290 \\
Teste 4 (fezes) & 91,48 & 4248,08 & 17,88 & 2,719 \\
Média & 91,52 & 4234,58 & 17,57 & 2,3007 \\
Ração teste & 87,69 & 3772,16 & 15,05 & 0,858 \\
Ração basal & 87,81 & 3777,56 & 14,82 & 0,944 \\
Urucum & 86,71 & 3743,21 & 14,73 & --- \\
\hline
\end{tabular}


Tabela A3. Composição das amostras de fezes, ração basal, ração teste e urucum, em matéria seca (Experimento I).

\begin{tabular}{cccc}
\hline Amostra & $\begin{array}{c}\text { Energia bruta } \\
(\mathrm{kcal} / \mathrm{g})\end{array}$ & $\begin{array}{c}\text { Proteína bruta } \\
(\%)\end{array}$ & $\begin{array}{c}\mathrm{Cr}_{2} \mathrm{O}_{3} \\
(\%)\end{array}$ \\
\hline Basal 1 (fezes) & 4309,04 & 19,19 & 2,984 \\
Basal 2 (fezes) & 4395,29 & 18,76 & 3,234 \\
Basal 3 (fezes) & 4440,20 & 17,49 & 2,712 \\
Basal 4 (fezes) & 4221,93 & 18,88 & 3,142 \\
Média & 4341,56 & 18,58 & 3,017 \\
Teste 1 (fezes) & 4530,01 & 19,00 & 2,190 \\
Teste 2 (fezes) & 4660,10 & 18,21 & 2,396 \\
Teste 3 (fezes) & 4675,00 & 20,03 & 2,497 \\
Teste 4 (fezes) & 4643,72 & 19,54 & 2,972 \\
Média & 4626,94 & 19,19 & 2,513 \\
Ração teste & 4301,69 & 17,16 & 0,978 \\
Ração basal & 4301,97 & 16,87 & 1,088 \\
Urucum & 4316,92 & 16,98 & --- \\
\hline
\end{tabular}


Tabela A4. Peso vivo dos animais ( $\mathrm{kg}$ ), obtidos semanalmente, considerando a média da unidade experimental (Experimento II).

\begin{tabular}{|c|c|c|c|c|c|c|c|}
\hline \multirow{2}{*}{$\begin{array}{c}\text { Dias de } \\
\text { experimento }\end{array}$} & \multirow[b]{2}{*}{ Bloco } & \multicolumn{5}{|c|}{ \% inclusão de resíduo de semente de urucum } & \multirow[b]{2}{*}{ Média } \\
\hline & & 0 & 2,5 & 5,0 & 7,5 & 10 & \\
\hline \multirow{5}{*}{$\begin{array}{c}0 \\
\text { dias }\end{array}$} & 1 & 27,45 & 27,40 & 27,40 & 27,40 & 28,00 & 27,53 \\
\hline & 2 & 25,25 & 26,00 & 25,30 & 25,40 & 25,30 & 25,45 \\
\hline & 3 & 19,35 & 19,85 & 20,15 & 20,05 & 19,75 & 19,83 \\
\hline & 4 & 17,45 & 16,65 & 18,20 & 16,50 & 17,00 & 17,16 \\
\hline & Média & 22,37 & 22,47 & 22,76 & 22,34 & 22,51 & 22,49 \\
\hline \multirow{5}{*}{$\begin{array}{c}7 \\
\text { dias }\end{array}$} & 1 & 30,55 & 34,20 & 35,35 & 35,50 & 33,95 & 33,91 \\
\hline & 2 & 30,60 & 32,55 & 31,60 & 33,10 & 31,30 & 31,83 \\
\hline & 3 & 26,10 & 23,80 & 25,80 & 24,90 & 25,80 & 25,28 \\
\hline & 4 & 25,05 & 23,65 & 25,90 & 23,10 & 25,85 & 24,71 \\
\hline & Média & 28,07 & 28,55 & 29,66 & 29,15 & 29,22 & 28,93 \\
\hline \multirow{5}{*}{$\begin{array}{c}14 \\
\text { dias }\end{array}$} & 1 & 36,55 & 38,70 & 40,65 & 41,90 & 39,10 & 39,38 \\
\hline & 2 & 36,45 & 37,75 & 36,60 & 38,45 & 35,10 & 36,87 \\
\hline & 3 & 31,50 & 27,40 & 30,65 & 29,35 & 31,05 & 29,99 \\
\hline & 4 & 31,75 & 30,70 & 32,45 & 29,30 & 32,30 & 31,30 \\
\hline & Média & 34,06 & 33,64 & 35,09 & 34,75 & 34,39 & 34,39 \\
\hline \multirow{5}{*}{$\begin{array}{c}21 \\
\text { dias }\end{array}$} & 1 & 43,35 & 43,50 & 47,05 & 48,00 & 45,30 & 45,44 \\
\hline & 2 & 42,55 & 43,35 & 42,00 & 44,05 & 40,50 & 42,49 \\
\hline & 3 & 36,85 & 33,75 & 35,35 & 34,05 & 37,90 & 35,58 \\
\hline & 4 & 37,80 & 37,10 & 38,95 & 34,55 & 38,05 & 37,29 \\
\hline & Média & 40,14 & 39,43 & 40,84 & 40,16 & 40,44 & 40,20 \\
\hline \multirow{5}{*}{$\begin{array}{c}28 \\
\text { dias }\end{array}$} & 1 & 48,80 & 49,30 & 54,75 & 55,15 & 53,25 & 52,25 \\
\hline & 2 & 49,85 & 50,00 & 48,45 & 50,70 & 46,05 & 49,01 \\
\hline & 3 & 42,15 & 39,05 & 39,95 & 39,75 & 45,45 & 41,27 \\
\hline & 4 & 44,30 & 44,60 & 46,40 & 39,55 & 45,35 & 44,04 \\
\hline & Média & 46,28 & 45,74 & 47,39 & 46,29 & 47,53 & 46,64 \\
\hline \multirow{5}{*}{$\begin{array}{c}35 \\
\text { dias }\end{array}$} & 1 & 55,30 & 55,10 & 62,80 & 60,80 & 58,75 & 58,55 \\
\hline & 2 & 57,50 & 56,85 & 55,05 & 58,25 & 52,20 & 55,97 \\
\hline & 3 & 49,45 & 46,55 & 45,00 & 46,60 & 52,15 & 47,95 \\
\hline & 4 & 50,75 & 52,80 & 52,75 & 47,65 & 52,50 & 51,29 \\
\hline & Média & 53,25 & 52,825 & 53,9 & 53,325 & 53,9 & 53,44 \\
\hline
\end{tabular}


Tabela A5. Resultados de consumo diário de ração (CDR, kg), considerando a média da unidade experimental (Experimento II).

\begin{tabular}{|c|c|c|c|c|c|c|c|}
\hline \multirow{2}{*}{$\begin{array}{c}\text { Dias de } \\
\text { Experimento }\end{array}$} & \multirow[b]{2}{*}{ Bloco } & \multicolumn{5}{|c|}{ \% de inclusão de resíduo de semente de urucum } & \multirow[b]{2}{*}{ Média } \\
\hline & & 0 & 2,5 & 5,0 & 7,5 & 10 & \\
\hline \multirow{5}{*}{$\begin{array}{l}0-7 \\
\text { dias }\end{array}$} & 1 & 1,027 & 1,520 & 1,785 & 1,738 & 1,319 & 1,478 \\
\hline & 2 & 1,231 & 1,616 & 1,483 & 1,677 & 1,338 & 1,469 \\
\hline & 3 & 1,054 & 0,907 & 1,308 & 1,259 & 1,434 & 1,192 \\
\hline & 4 & 1,687 & 1,351 & 1,541 & 0,962 & 1,457 & 1,400 \\
\hline & Média & 1,250 & 1,348 & 1,529 & 1,409 & 1,387 & 1,385 \\
\hline \multirow{5}{*}{$\begin{array}{l}7-14 \\
\text { dias }\end{array}$} & 1 & 1,557 & 1,412 & 1,707 & 1,895 & 1,565 & 1,627 \\
\hline & 2 & 1,608 & 1,740 & 1,530 & 1,676 & 1,404 & 1,592 \\
\hline & 3 & 1,393 & 1,150 & 1,195 & 1,196 & 1,554 & 1,298 \\
\hline & 4 & 2,095 & 1,927 & 2,117 & 1,772 & 1,841 & 1,950 \\
\hline & Média & 1,663 & 1,557 & 1,637 & 1,635 & 1,591 & 1,617 \\
\hline \multirow{5}{*}{$\begin{array}{c}14-21 \\
\text { dias }\end{array}$} & 1 & 1,911 & 1,701 & 2,146 & 2,166 & 2,035 & 1,992 \\
\hline & 2 & 2,043 & 1,871 & 2,024 & 2,015 & 1,680 & 1,927 \\
\hline & 3 & 1,779 & 1,747 & 1,523 & 1,530 & 2,078 & 1,731 \\
\hline & 4 & 2,257 & 2,110 & 2,283 & 1,818 & 2,078 & 2,109 \\
\hline & Média & 2,00 & 1,86 & 1,99 & 1,88 & 1,97 & 1,940 \\
\hline \multirow{5}{*}{$\begin{array}{c}21-28 \\
\text { dias }\end{array}$} & 1 & 2,473 & 1,963 & 2,332 & 2,132 & 2,079 & 2,196 \\
\hline & 2 & 2,069 & 2,113 & 1,993 & 2,199 & 1,777 & 2,030 \\
\hline & 3 & 1,717 & 1,838 & 1,512 & 1,585 & 2,407 & 1,812 \\
\hline & 4 & 2,527 & 2,525 & 2,497 & 2,130 & 2,332 & 2,402 \\
\hline & Média & 2,20 & 2,11 & 2,08 & 2,01 & 2,15 & 2,110 \\
\hline \multirow{5}{*}{$\begin{array}{c}28-35 \\
\text { dias }\end{array}$} & 1 & 2,001 & 1,938 & 2,593 & 2,119 & 2,176 & 2,165 \\
\hline & 2 & 2,313 & 2,200 & 2,252 & 2,313 & 1,881 & 2,192 \\
\hline & 3 & 2,100 & 2,204 & 2,219 & 3,156 & 2,199 & 2,376 \\
\hline & 4 & 2,638 & 3,141 & 2,484 & 2,533 & 2,524 & 2,664 \\
\hline & Média & 2,263 & 2,371 & 2,387 & 2,530 & 2,195 & 2,349 \\
\hline \multirow{5}{*}{$\begin{array}{l}0-35 \\
\text { dias }\end{array}$} & 1 & 1,794 & 1,707 & 2,113 & 2,010 & 1,835 & 1,892 \\
\hline & 2 & 1,853 & 1,908 & 1,857 & 1,976 & 1,616 & 1,842 \\
\hline & 3 & 1,609 & 1,569 & 1,552 & 1,745 & 1,935 & 1,682 \\
\hline & 4 & 2,241 & 2,211 & 2,184 & 1,843 & 2,047 & 2,105 \\
\hline & Média & 1,874 & 1,849 & 1,927 & 1,894 & 1,858 & 1,880 \\
\hline
\end{tabular}


Tabela A6. Resultados de ganho diário de peso (GDP, kg), considerando a média da unidade experimental (Experimento II).

\begin{tabular}{|c|c|c|c|c|c|c|c|}
\hline \multirow{2}{*}{$\begin{array}{c}\text { Dias de } \\
\text { Experimento }\end{array}$} & \multirow[b]{2}{*}{ Bloco } & \multicolumn{5}{|c|}{ \% de inclusão de resíduo de semente de urucum } & \multirow[b]{2}{*}{ Média } \\
\hline & & 0 & 2,5 & 5,0 & 7,5 & 10 & \\
\hline \multirow{5}{*}{$\begin{array}{c}0-7 \\
\text { dias }\end{array}$} & 1 & 0,443 & 0,971 & 1,135 & 1,157 & 0,850 & 0,911 \\
\hline & 2 & 0,764 & 0,936 & 0,900 & 1,100 & 0,857 & 0,911 \\
\hline & 3 & 0,964 & 0,564 & 0,807 & 0,693 & 0,864 & 0,778 \\
\hline & 4 & 1,086 & 1,000 & 1,100 & 0,943 & 1,264 & 1,079 \\
\hline & Média & 0,814 & 0,868 & 0,986 & 0,973 & 0,959 & 0,920 \\
\hline \multirow{5}{*}{$\begin{array}{l}7-14 \\
\text { dias }\end{array}$} & 1 & 0,857 & 0,642 & 0,757 & 0,914 & 0,735 & 0,781 \\
\hline & 2 & 0,835 & 0,742 & 0,714 & 0,764 & 0,628 & 0,737 \\
\hline & 3 & 0,771 & 0,514 & 0,692 & 0,635 & 0,750 & 0,672 \\
\hline & 4 & 0,892 & 1,007 & 0,935 & 0,885 & 0,921 & 0,928 \\
\hline & Média & 0,839 & 0,726 & 0,775 & 0,800 & 0,759 & 0,780 \\
\hline \multirow{5}{*}{$\begin{array}{c}14-21 \\
\text { dias }\end{array}$} & 1 & 0,971 & 0,685 & 0,914 & 0,871 & 0,885 & 0,865 \\
\hline & 2 & 0,871 & 0,800 & 0,771 & 0,800 & 0,685 & 0,785 \\
\hline & 3 & 0,764 & 0,907 & 0,671 & 0,671 & 0,979 & 0,798 \\
\hline & 4 & 0,864 & 0,914 & 0,929 & 0,750 & 0,821 & 0,856 \\
\hline & Média & 0,87 & 0,83 & 0,82 & 0,77 & 0,84 & 0,826 \\
\hline \multirow{5}{*}{$\begin{array}{c}21-28 \\
\text { dias }\end{array}$} & 1 & 0,778 & 0,828 & 1,100 & 1,021 & 1,135 & 0,972 \\
\hline & 2 & 1,042 & 0,950 & 0,921 & 0,950 & 0,792 & 0,931 \\
\hline & 3 & 0,757 & 0,757 & 0,657 & 0,814 & 1,078 & 0,813 \\
\hline & 4 & 0,928 & 1,071 & 1,064 & 0,714 & 1,042 & 0,964 \\
\hline & Média & 0,88 & 0,90 & 0,94 & 0,87 & 1,01 & 0,920 \\
\hline \multirow{5}{*}{$\begin{array}{c}28-35 \\
\text { dias }\end{array}$} & 1 & 0,929 & 0,829 & 1,150 & 0,807 & 0,786 & 0,900 \\
\hline & 2 & 1,093 & 0,979 & 0,943 & 1,079 & 0,879 & 0,995 \\
\hline & 3 & 1,043 & 1,071 & 0,721 & 0,979 & 0,957 & 0,954 \\
\hline & 4 & 0,921 & 1,171 & 0,907 & 1,157 & 1,021 & 1,035 \\
\hline & Média & 0,997 & 1,013 & 0,930 & 1,006 & 0,911 & 0,971 \\
\hline \multirow{5}{*}{$\begin{array}{l}0-35 \\
\text { dias }\end{array}$} & 1 & 0,796 & 0,791 & 1,011 & 0,954 & 0,879 & 0,886 \\
\hline & 2 & 0,921 & 0,881 & 0,850 & 0,939 & 0,769 & 0,872 \\
\hline & 3 & 0,860 & 0,763 & 0,710 & 0,759 & 0,926 & 0,804 \\
\hline & 4 & 0,951 & 1,033 & 0,987 & 0,890 & 1,014 & 0,975 \\
\hline & Média & 0,882 & 0,867 & 0,890 & 0,886 & 0,897 & 0,884 \\
\hline
\end{tabular}


Tabela A7. Resultados de conversão alimentar (CA), considerando a média da unidade experimental (Experimento II).

\begin{tabular}{|c|c|c|c|c|c|c|c|}
\hline \multirow{2}{*}{$\begin{array}{c}\text { Dias de } \\
\text { Experimento }\end{array}$} & \multirow[b]{2}{*}{ Bloco } & \multicolumn{5}{|c|}{ \% de inclusão de resíduo de semente de urucum } & \multirow[b]{2}{*}{ Média } \\
\hline & & 0 & 2,5 & 5,0 & 7,5 & 10 & \\
\hline \multirow{5}{*}{$\begin{array}{c}0-7 \\
\text { dias }\end{array}$} & 1 & 2,320 & 1,565 & 1,572 & 1,502 & 1,552 & 1,702 \\
\hline & 2 & 1,611 & 1,727 & 1,649 & 1,524 & 1,561 & 1,614 \\
\hline & 3 & 1,093 & 1,607 & 1,621 & 1,816 & 1,659 & 1,559 \\
\hline & 4 & 1,553 & 1,350 & 1,400 & 1,021 & 1,152 & 1,295 \\
\hline & Média & 1,644 & 1,562 & 1,560 & 1,465 & 1,481 & 1,543 \\
\hline \multirow{5}{*}{$\begin{array}{l}7-14 \\
\text { dias }\end{array}$} & 1 & 1,816 & 2,196 & 2,255 & 2,073 & 2,128 & 2,094 \\
\hline & 2 & 1,924 & 2,342 & 3,142 & 2,193 & 2,234 & 2,367 \\
\hline & 3 & 1,805 & 2,237 & 1,725 & 1,881 & 2,073 & 1,944 \\
\hline & 4 & 2,346 & 1,914 & 2,263 & 2,000 & 1,998 & 2,104 \\
\hline & Média & 1,973 & 2,172 & 2,346 & 2,037 & 2,108 & 2,127 \\
\hline \multirow{5}{*}{$\begin{array}{c}14-21 \\
\text { dias }\end{array}$} & 1 & 1,967 & 2,480 & 2,347 & 2,485 & 2,298 & 2,315 \\
\hline & 2 & 2,345 & 2,483 & 2,624 & 2,518 & 2,450 & 2,484 \\
\hline & 3 & 2,327 & 1,926 & 2,269 & 2,278 & 2,124 & 2,185 \\
\hline & 4 & 2,611 & 2,308 & 2,458 & 2,424 & 2,530 & 2,466 \\
\hline & Média & 2,31 & 2,30 & 2,42 & 2,43 & 2,35 & 2,363 \\
\hline \multirow{5}{*}{$\begin{array}{c}21-28 \\
\text { dias }\end{array}$} & 1 & 3,176 & 2,369 & 2,120 & 2,088 & 1,830 & 2,317 \\
\hline & 2 & 1,984 & 2,225 & 2,162 & 2,315 & 2,242 & 2,186 \\
\hline & 3 & 2,268 & 2,428 & 2,302 & 1,946 & 2,232 & 2,235 \\
\hline & 4 & 2,721 & 2,356 & 2,346 & 2,982 & 2,237 & 2,528 \\
\hline & Média & 2,54 & 2,34 & 2,23 & 2,33 & 2,14 & 2,316 \\
\hline \multirow{5}{*}{$\begin{array}{c}28-35 \\
\text { dias }\end{array}$} & 1 & 2,155 & 2,339 & 2,254 & 2,626 & 2,769 & 2,429 \\
\hline & 2 & 2,116 & 2,249 & 2,388 & 2,144 & 2,141 & 2,208 \\
\hline & 3 & 2,014 & 2,057 & 3,076 & 3,225 & 2,298 & 2,534 \\
\hline & 4 & 2,863 & 2,681 & 2,738 & 2,189 & 2,471 & 2,588 \\
\hline & Média & 2,287 & 2,332 & 2,614 & 2,546 & 2,420 & 2,440 \\
\hline \multirow{5}{*}{$\begin{array}{l}0-35 \\
\text { dias }\end{array}$} & 1 & 2,255 & 2,157 & 2,089 & 2,107 & 2,089 & 2,139 \\
\hline & 2 & 2,011 & 2,165 & 2,184 & 2,105 & 2,103 & 2,114 \\
\hline & 3 & 1,871 & 2,057 & 2,186 & 2,300 & 2,090 & 2,101 \\
\hline & 4 & 2,355 & 2,140 & 2,213 & 2,071 & 2,018 & 2,159 \\
\hline & Média & 2,123 & 2,130 & 2,168 & 2,146 & 2,075 & 2,128 \\
\hline
\end{tabular}


Tabela A8. Registro de temperaturas $\left({ }^{\circ} \mathrm{C}\right)$ máximas e mínimas durante o período experimental (Experimento II)

\begin{tabular}{|c|c|c|}
\hline Data & Mínima & Máxima \\
\hline $01 / 04$ & --- & --- \\
\hline $02 / 04$ & --- & --- \\
\hline 03/04 & 19,0 & 21,5 \\
\hline 04/04 & 18,5 & 29,0 \\
\hline $05 / 04$ & 20,0 & 31,5 \\
\hline 06/04 & 21,5 & 32,0 \\
\hline $07 / 04$ & 21,5 & 32,5 \\
\hline 08/04 & 21,0 & 32,0 \\
\hline 09/04 & 21,5 & 32,5 \\
\hline $10 / 04$ & 22,5 & 29,0 \\
\hline $11 / 04$ & 21,5 & 32,0 \\
\hline $12 / 04$ & 21,5 & 32,5 \\
\hline $13 / 04$ & 17,5 & 28,5 \\
\hline $14 / 04$ & 17,0 & 28,5 \\
\hline $15 / 04$ & 17,5 & 28,5 \\
\hline $16 / 04$ & 18,0 & 30,0 \\
\hline $17 / 04$ & 17,5 & 29,0 \\
\hline $18 / 04$ & 17,0 & 29,0 \\
\hline $19 / 04$ & 17,0 & 29,0 \\
\hline $20 / 04$ & 17,5 & 32,0 \\
\hline $21 / 04$ & 17,0 & 32,0 \\
\hline $22 / 04$ & 21,0 & 32,0 \\
\hline $23 / 04$ & 21,5 & 31,0 \\
\hline $24 / 04$ & 22,0 & 32,0 \\
\hline $25 / 04$ & 21,5 & 32,0 \\
\hline $26 / 04$ & 18,5 & 31,5 \\
\hline $27 / 04$ & 17,5 & 31,0 \\
\hline $28 / 04$ & 18,5 & 32,0 \\
\hline $29 / 04$ & 17,5 & 32,0 \\
\hline $30 / 04$ & 18,0 & 32,0 \\
\hline $01 / 05$ & 17,5 & 31,0 \\
\hline $02 / 05$ & 18,0 & 31,5 \\
\hline $03 / 05$ & 19,5 & 32,0 \\
\hline $04 / 05$ & 18,5 & 32,0 \\
\hline $05 / 05$ & 16,5 & 30,5 \\
\hline Médias & 19,1 & 30,7 \\
\hline
\end{tabular}

